3.

\title{
URBANI RAZVITAK SPLITA IZMEĐU DVA SVJETSKA RATA
}

\section{Stanko Piplović}

UDK: 711.4(497.5 Split)“1918/1941“

Pregledni rad

Sažetak: Književnik Vladan Desnica proveo je razdoblje između dvaju svjetskih ratova najvećim dijelom u Splitu. Bilo je to vrijeme modernoga urbanog preobražaja grada koji je u Kraljevini SHS/Jugoslaviji bio daleko najveći urbani centar na obali Jadranskog mora. Usvajanjem Regulacionog plana Splita u proceduri međunarodnog natječaja (1923. 1926.), zalaganjima gradske političke, intelektualne i poduzetničke elite - koliko god razvojne koncepcije i interesi bili različiti - Split se u dvadesetak godina gospodarski, kulturno i graditeljski uvelike preobrazio. Njegov vanjski izgled i ugođaji prostora mijenjali su se gotovo iz dana u dan. Sagrađene su brojne građevine, uključujući i one za javne potrebe i kulturu. Usporenije je izlazio iz svoje prometne izoliranosti, što ipak nije sprečavalo sve veću cirkulaciju ljudi s raznih strana, uključujući i turističku. Neovisno o svim ograničenjima, kreativnost se očitovala u raznim domenama, naročito u kulturnoj i umjetničkoj. Dinamično, kreativno okružje svakako je utjecalo i na Vladana Desnicu u njegovim formativnim umjetničkim fazama.

Ključne riječi: Split, 20. stoljeće, urbanizam, ambijent, graditeljstvo

\section{UVOD}

[] 19. stoljeću Split je mali grad na periferiji Habsburške Monarhije. Počinje se razvijati tek od sredine stoljeća. Ipak, nedostajale su mu prometna infrastruktura koja bi ga povezala sa zaleđem i tekuća voda, neophodne gospodarstvu. Dugo se raspravljalo o željezničkom spoju s unutrašnjošću i to u pravcu središta države i sjeveroistoka, gdje su bile sirovine. Nastojalo se da Split postane izvozna i tranzitna luka. U tu svrhu najprije je izgrađen lukobran. Nakon toga se pristupilo izgradnji pristaništa za veće parobrode. Među značajnijim građevinama iz tog razdoblja su dva kazališta, Arheološki muzej, Lučka kapetanija, Režija duhana, Obrtnička škola, crkve sv. Petra, Ančela i Gospe od Dobrića, samostan klarisa na Lučcu i biskupska palača. 
Nakon 1918., u novim društvenim uvjetima nakon gubitka Rijeke i Zadra, koji su pripali Italiji, Split je postao glavna pomorska luka i važno prometno središte u Kraljevini SHS. U njega dolaze brojni činovnici iz pokrajinskih ustanova i državnih ureda u Zadru, a naseljavaju se i stanovnici iz obližnjih pasivnih mjesta u potrazi za boljim životom. Grad se naglo širi u okolicu. Za njegov uspješan razvitak posebno je zaslužan odvjetnik dr. Ivo Tartaglia, koji je 1918. izabran za gradonačelnika. Tu je dužnost uspješno vršio punih deset godina. On je redovito predsjedavao ocjenjivačkim odborima prilikom raspisivanja brojnih natječaja za izradu idejnih rješenja novih javnih zgrada. Tada su se rješavala važna pitanja elektrifikacije grada, završetka njegovog željezničkog povezivanja s unutrašnjošću, izgradnje nove luke i komunalne infrastrukture. ${ }^{1}$

\section{REgULACiONi PLAN}

Još pred rat osjećala se potreba da se planski osmisli ubrzano širenje i izgradnja Splita. Nije se više moglo dopustiti da privatni interesi priječe javne. Nastupom mira izabran je poseban odbor za izradu Regulacionog plana. Osnovni problemi koji su se morali riješiti bili su položaj novoga željezničkog kolodvora i nove trgovačke luke, glavne prometnice i podjela grada na zone. Konačno je 1923. raspisan međunarodni natječaj za njegovu izradu. U ocjenjivačkom sudu bili su domaći i strani stručnjaci: prof. Hermann Jansen iz Berlina, prof. Léon Jaussely iz Pariza, ing. Mate Jurković iz Zagreba te arh. Fabjan Kaliterna, ing. Petar Senjanović, ing. Lovro Manola, dr. Frane Bulić, dr. Ivo Tartaglia, ing. Dane Matošić i dr. Jozo Arambašin, svi iz Splita. Rok za predaju radova bio je 30. travnja 1924., ali je produžen do 1. rujna. Prva nagrada nije dodijeljena, a druga i treća su spojene pa su polovicama iznosa nagrađena dva rada mladoga njemačkog arhitekta Wernera Schürmanna iz Haaga te zajednički rad grupe autora Erwina Böcka, Alfreda Schmidta, Franza Zottera i Maxa Theuera iz Beča. Kao najbolje usvojeno je Schürmannovo rješenje. Kasnije je on na poziv Općine došao u dva navrata u Split i prema primjedbama napravio konačni plan. Njegovo rješenje je bilo racionalno pa je dobro primljeno i u javnosti. Općinsko vijeće jednoglasno je prihvatilo Plan na sjednici 24. rujna 1926. Izabran je Odbor za njegovo provođenje pa je već 1931. donekle promijenjen.

Glavnu okosnicu prostorne strukture grada činio je novi trg sjeverno od grada. Odatle se nastavljala široka promenada do brijega Glavičine. Tamo su na vidikovcu bili smješteni kavana i restoran s pogledom na okolicu. Među javnim zdanjima bilo je novo kazalište $s$ koncertnom dvoranom i katedrala u istočnom dijelu Spinuta, a od gospodarskih postrojenja trgovačka luka s gatovima i željeznička postrojenja na sjevernom dijelu poluotoka. Planom je bila predviđena sportska zona na Mejama na zaravni ispred poluotoka Sustipana, gdje su smještena igrališta i stadion.

16. lipnja 1931. donesen je Građevinski zakon - prvi koji je važio za cijelu državu, što je bio značajan napredak u stručnom zakonodavstvu. U njemu su po prvi put unesene odred-

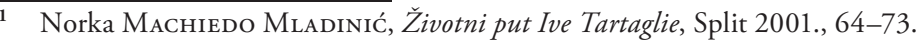




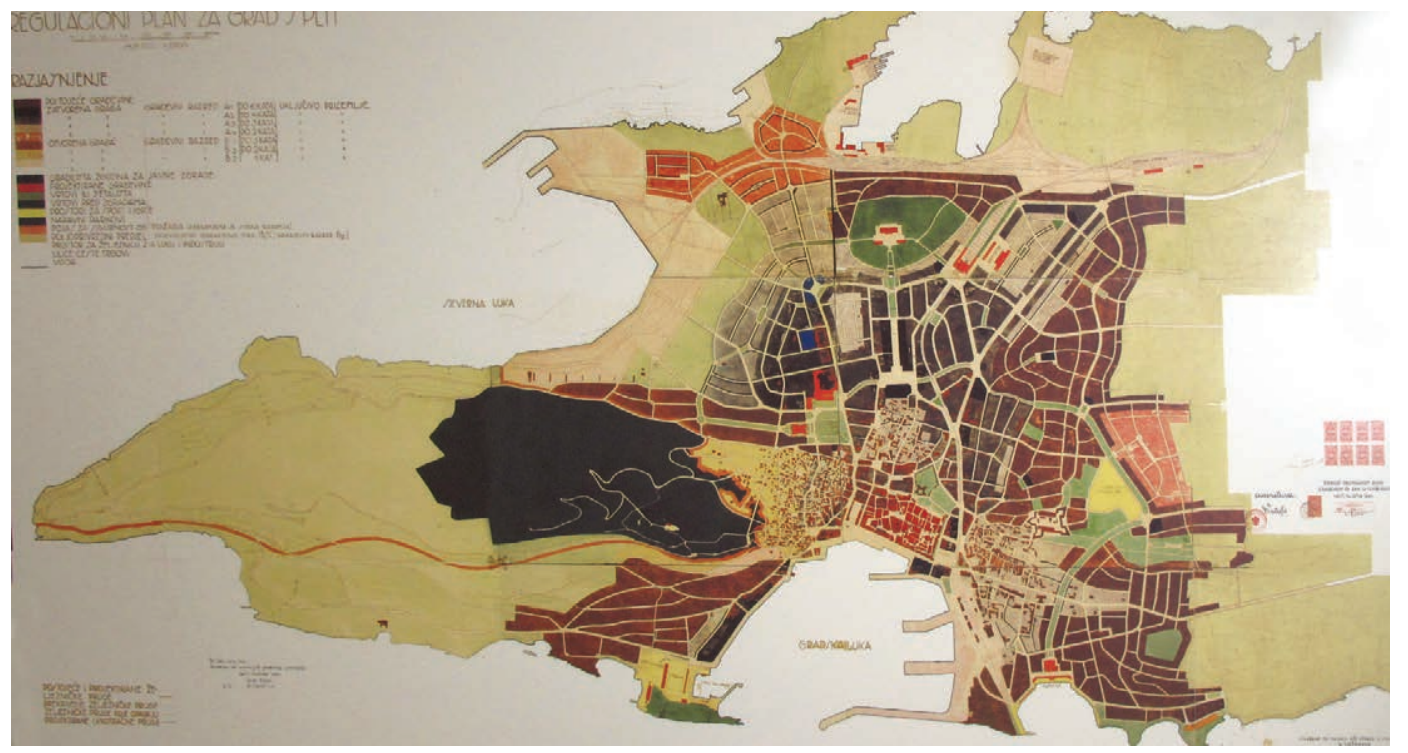

Sl. 1. Regulacioni plan Splita prema prihvaćenom rješenju njemačkog arhitekta Wernera Schürmanna

be za uređenje gradova i naselja kao cjelina. ${ }^{2}$ Do tada su u građevinarstvu služili zastarjeli lokalni propisi. Plan je formalno trebalo usuglasiti s novim odredbama. U skladu s tim osnovan je Građevinski odbor kao savjetodavni organ Općine za tehnička i građevinska pitanja. Zatim je 1932. imenovan Regulacioni odbor za provođenje plana. Korekcije plana završene su 1936. pa je elaborat upućen Ministarstvu građevina na odobrenje. Taj ključni urbanistički dokument važio je sve do Drugoga svjetskog rata, ali je u provedbi doživio dosta promjena. U svibnju 1938. vraćen je Regulacioni plan u Beograd na odobrenje. Nakon cijele i duge zakonske procedure i daljnjih izmjena u lipnju 1940. godine jednoglasno su usvojeni Plan i Uredba za njegovo izvođenje. ${ }^{3}$

Grad se najviše širio prema istoku, gdje su bile atraktivne i osunčane morske plaže Bačvica i Firula, te prema sjeveroistoku, u predjel Gripa. Među važnim pitanjima koja su se rješavala bila su izgradnja rezervoara za vodu na uzvisini Gripa, gradnja pučkih škola, regulacija ulica, javnih spomenika, carinskih skladišta i gradnja Banske palače. Međutim, početkom tridesetih godina zemlju je zahvatila gospodarska kriza, što se znatno odrazilo na građevinsku djelatnost. Poboljšanjem prilika istočni dio Splita dobro je komunalno i infrastrukturno uređen, što je ubrzalo njegovu izgradnju. Na sjevernoj strani splitskog poluotoka formirale su se industrijska i prometna zona. Porasla je i stambena izgradnja. Ipak, unatoč velikom napretku u razvitku Splita kod javnih gradnja bilo je teškoća zbog nedostatka sredstava, neuspjelih licitacija i sporosti građenja. Osobiti problemi pojavili su se kod gradnja gimnazijskih zgrada i Banske palače. Posljednjih godina dosta se gradilo

\footnotetext{
Petar Senjanović, „Novi građevinski zakon“, Tehnički list, 13/1931., br. 11, 157 i 159.

3 Darovan TušEk, Arhitektonski natječaji u Splitu 1918-1941., Split 1994., 32-41; Stanko PiPlović, Izgradnja Splita između svjetskih ratova, Split 2008., 24-34.
} 
na Lovretu sjeverno od grada, gdje se planiralo smjestiti njegovo središte. Posebno mnogo gradilo se 1939. godine. Pred rat, zbog međunarodne situacije, rasle su cijene građevinskog materijala pa su poduzetnici često riskirali gubitak na unaprijed dogovorenim poslovima

\section{STAMBENA ARHITEKTURA}

Koncem 19. stoljeća u Splitu se još uvijek gradilo po ustaljenim pravilima prošlosti, ali ipak se osjećao duh novog vremena. 1920-ih projektiralo se prema obrascima između tradicionalnog i suvremenog, regionalnog i internacionalnog $s$ većim naznakama individualnog i kreativnog naboja. Kuća u nizu na Trumbićevoj obali iz 1910-ih godina među zgradama je koje najavljuju novi pristup, ali na kojima se još uvijek odražavaju koncepcije rasporeda iz neposredne prošlosti. Pročelje joj je još uvijek potpuno simetrično, a njezina dekoracija asocira stilske oznake. ${ }^{4}$

Tako je dosta brzo došlo do preokreta u shvaćanjima arhitektonske teorije i prakse. To je bila posljedica novih društvenih odnosa i razvitka tehničkih znanosti. Mladići iz Splita u prijelaznom razdoblju studirali su najviše u Pragu, avangardnom središtu novih zasada, a zatim u Zagrebu kada je tamo bila otvorena Visoka tehnička škola. Prihvatili su moderne funkcionalističke ideje koje su na tim fakultetima zastupane. Primjenjivali su se i novi građevinski materijali i konstrukcije. Ipak, još neko vrijeme u oblikovanju i prostornoj koncepciji prisutne su tradicionalne zasade secesije pa i historicizma, naročito na javnim građevinama.

U gradu je djelovao veći broj talentiranih arhitekata koji su radikalno mijenjali njegov sadržaj i izgled. Među prvima koji su odlučno istupili su arhitekti Josip Kodl iz Češke i mladi Milorad Družeić, projektant sportskih, stambenih, prometnih, školskih i upravnih građevina. ${ }^{5}$

Stambena gradnja u Splitu, pored svih teškoća i zastoja, bila je vrlo živa. Na tome se posebno angažirala Općinska uprava, koja je pripremala gradilišta, uređivala nove ulice i komunalne instalacije. Najistaknutiji graditelj u cijelom međuratnom razdoblju bio je arh. Fabjan Kaliterna. On se u početku svoga djelovanja oslanjao na mjesnu tradiciju i slikovitost secesije. U Splitu i okolici projektirao je oko stotinu kuća koje su dale posebno obilježje čitavom međuratnom razdoblju razvitka grada. ${ }^{6} \mathrm{U}$ tom ubrzanom procesu transformacije sudjelovali su i istaknuti arhitekti iz cijele države, a neki i iz inozemstva. Među njima su bili Edo Šen, Juraj Denzler, Mladen Kauzlarić, Kazimir Ostrogović i Vladimir Turina iz Zagreba, Bogdan Nestorović, Nikola Dobrović i Branislav Kojić iz Beograda, David Bunetta sa

4 Edo ŠEGVIĆ, Dvi-tri fete Matejuške, Split 2013., 86-97; Edo ŠEGvić, „Kuća Arambašin“, Kulturna baština, 39/2013., 251-254.

5 Stanko Piplović, „Arhitekt Milorad Družeić“, Kulturna baština, 37/2011., 263-269.

6 Duško Keč́еmet, „Stambena arhitektura u Splitu u razdoblju između dva svjetska rata“, Arhitektura, 42-44/1989.1991., br. 1-3, 25-27; Duško KeČкemet, „Arh. Fabijan Kaliterna“, Slobodna Dalmacija (Split), br. 9763, 21. 8. 1976., 6. 
Sušaka, Ivan Vurnik iz Ljubljane, Mate Baylon iz Sarajeva i brojni drugi. Tako je Split postao svojevrstan poligon promidžbe novih rješenja i odraz različitih utjecaja iz šire okoline.

Najveći problem je bila stambena izgradnja. Naseljavanje pučanstva iz okolice izazvalo je u poslijeratnim godinama veliku stambenu krizu. Broj stanovnika stalno je rastao i to od otprilike 24000 na 45000 tisuća ljudi. U takvoj situaciji Općinska uprava je odlučila 1920. graditi dvije zgrade sa zdravim stanovima i to jednu istočno od grada na slobodnim prostorima Gripa te drugu na Starom pazaru, koja nije izvedena. Da bi se ubrzala gradnja, osnovano je Splitsko građevno poduzeće u koje je ušla Općina i više banaka. Kao jedna od lokacija za opsežniju stambenu izgradnju odabrano je zemljište na Novom pazaru u predjelu Manuš. U tu svrhu sastavljen je 1921. godine konzorcij. Odmah je raspisan natječaj za Generalnu osnovu. Rok za predaju radova je bio 30. travnja. Prva nagrada je dodijeljena arh. Danilu Žagaru, a druga arh. Zvonimiru Celiću. Iste godine raspisan je natječaj za gradnju triju zgrada. Na taj način je do 1928. izgrađeno naselje od šest višekatnica. U njihovom vanjskom oblikovanju još uvijek su vidljivi utjecaji tradicionalne arhitekture. Plan je samo djelomično ostvaren, jer su izostali planirani prateći sadržaji. ${ }^{7}$

$\mathrm{Za}$ rješavanju podizanja stanova formirane su razne asocijacije kao Zadruga za gradnju činovničkih stanova 1921. godine, za suradnju je bila zainteresirana Zadruga građevinskih i srodnih obrta, a gradila je i Gradska štedionica.

Godine 1924. građevinska djelatnost je bila vrlo slaba, došlo je do zastoja zbog pomanjkanja kredita. I tek je 1927. ponovno živnula, osobito na bližoj periferiji. Najjača je aktivnost bila u predjelu tadašnje Balkanske ceste i gornjem dijelu Manuša, ali se i u drugim smjerovima dosta gradilo. Pozitivan trend nastavljen je i u idućoj godini. Zatim je ponovno došlo do zastoja. Tome je djelomično bio uzrok novi porezni zakon. Kako bi se ipak pospješila građevinska djelatnost, dopunom propisa odobrene su olakšice u plaćanju državnih doprinosa.

Općinska uprava je 1928. godine sagradila za siromašne radničke obitelji na predjelu Gripa koloniju od pet jednokatnica s 44 stana uz koje su bili vrtovi. Projektant je bio arh. Nikola Armanda. Bile su to zgrade skromne opreme i jednostavnog izgleda. ${ }^{8}$ Osobito je teško bilo stanje 1932. zbog svjetske gospodarske krize. Izgubljeno je povjerenje u banke pa su mnogi dizali svoje uloge i investirali ih u nekretnine, što se smatralo sigurnijim. Ipak je i tada izgrađeno 400 stanova. Posljedica je bila višak stanova na tržištu jer nije postojala tolika potražnja. Mnogi su bili prazni čak i u središtu grada. Slično je bilo i u idućoj godini. Stoga su nešto snižene stanarine. Već iduće godine smanjio se broj molba za novogradnje. Građevinska je djelatnost stalno oscilirala. Mnoge opsežne zamisli nisu ostvarene, a došlo je i do krize u građevinskim obrtima.

Stambeno pitanje bio je socijalni problem koji je pogađao stanovnike slabijeg imovinskog stanja. Ipak je građevinska djelatnost, pored povremenih kriza, bila prilično živa. Međutim, nedostajalo je jeftinih stanova. Općina Split je u srpnju 1938. uputila predstavku

Stanko Piplović, „Graditelji braća Žagar“, Kulturna baština, 32/2005., 334-338.

8 Robert Plejıć, „Splitski arhitekt Niko Armanda, arhitektonski modernizam i povijesni prostor“, Kulturna baština, 37/2011., 231. 
Centralnom odboru za posredovanje rada u Beogradu. Molila je za pomoć za izgradnju stotinjak malih radničkih stanova, čime bi se riješilo važno društveno pitanje. Posebno je bilo teško stanje u povijesnoj jezgri. Sirotinja je živjela u nezdravim i zapuštenim kućama starog grada, koje su bile prave jazbine i leglo tuberkuloze s velikom smrtnošću. Predlagalo se rušenje mračnih zgrada, ali se nitko nije pozabavio sustavnim rješavanjem. I Udruženje stanara pokušalo je nešto učiniti. Dolazilo je i do štrajka radnika, što je dodatno otežavalo rješenje tog pitanja.

Godine 1938. podignuto je stotinjak kuća. Gradilo se u svim predjelima, a najviše na Gripama, Mejama i Bačvicama. Cijene zemljišta su se zbog velike potražnje povećavale. Stambeno pitanje u Splitu bilo je stalno složeno.

Posebno aktivan u projektiranju stanova bio je Fabjan Kaliterna. Najplodnije je prvo razdoblje njegovog djelovanja u Splitu od 1921. godine. U njegovim su se građevinama ogledale slikovitost secesije i stanovita romantika. Oko 100 stambenih i drugih kuća koje je projektirao do 1941. godine u dobroj je mjeri utjecalo na ukupnu sliku grada.?

Među ostvarenjima stambenih zgrada toga vremena karakteristična je po svojim dinamičnim linijama uglovnica koju je projektirao Doris Žagar na uglu Istarske i Riječke ulice na Manušu iz 1936. Kuća Marangunić u Zrinsko-frankopanskoj ulici arhitekta Frane Cote iz 1938. godine ističe se jednostavnim elementima bez dekoracija, kojima je postignut monumentalni izraz. Među arhitektima koji su dosta radili na izgradnji stambenih zgrada u vremenu od 1928. do 1942. bio je i praški đak Zlatibor Lukšić. On je za to vrijeme napravio projekte za 12 stambenih zgrada. ${ }^{10}$

Nastupom tridesetih godina djelatan je u Splitu inženjer Hranko Smodlaka. Još 1929. napravio je nacrt vile svog oca, dr. Josipa Smodlake, odvjetnika i političara, na Bačvicama. Zatim je napravio projekt za stambenu trokatnicu u današnjoj Ulici kralja Zvonimira pa jednokatnicu za svoju obitelj u Vrazovoj ulici. I on je, kao i neki njegovi kolege, u kreativnoj evoluciji prešao put od ugledanja na dalmatinsko pučko graditeljstvo do modernog pročišćenog izričaja. Smodlaka se inače bavio pitanjima prostornog uređenja i graditeljskog nasljeđa Splita s teoretskog i praktičnog stajališta. ${ }^{11}$

Nekoliko zanimljivih stambenih zgrada čistih linija u Splitu projektirao je arhitekt Lavoslav Horvat, koji je inače djelovao u Zagrebu. Po njegovim su projektima podignute zgrade $\mathrm{u}$ istočnim elitnim rezidencijalnim predjelima Firule i Zenta, okrenute jugu, prema moru. Ističe se kuća Ilić ekspresionističkom igrom kubnih i zaobljenih dijelova. Za razliku od nje zgrade Grisogono i Buj predstavljaju čvrste i elementarne volumene mirnih linija. Tamo je i samostalna dvokatna kuća Čičin-Šain te kuća odvjetnika Korlaeta iz 1932. godine. Među Horvatovim obiteljskim zgradama s regionalnim arhitektonskim značajkama je kuća Jerka Čulića iz istog vremena, koja se skladno uklopila u ozelenjeni krajolik.

\footnotetext{
9 D. KeČKemet, „Arh. Fabijan Kaliterna“, 6.

10 Lida Roje Depolo - Aleksandar Laslo, Frane Cota, Zagreb 1995., 63 i 87. Usp. i letak-katalog predavanja Slavka Muljačića „Zlato Lukšić arhitekt dvaju razdoblja“. Predavanje je održano u Društvu arhitekata Splita 1989. godine.

11 Dragutin Matošić, „Hranko Smodlaka“, Kulturna baština, 33/2006., 135-138; Stanko Piplović, „Stručno djelovanje Hranka Smodlake“, Kulturna baština, 33/2006., 153-161.
} 


\section{JAVNE GRAĐEVINE}

Naraslom gradu i novim upravnim, gospodarskim i kulturnim funkcijama koje je dobio bile su potrebne nove prikladne građevine. Za izradu idejnih rješenja raspisivali su se javni natječaji. $\mathrm{Na}$ čelu odbora punih deset godina bio je redovito gradonačelnik dr. Ivo Tartaglia. U ovom razdoblju bilo je ukupno 27 natječaja.

Trebalo je u prvom redu zadovoljiti potrebe općinskih i državnih ureda. Općinska uprava je bila u staroj vijećnici na Narodnom trgu, a neki odjeli na drugim mjestima. Poslovi su postali složeniji pa je odlučeno sve službe objediniti u novim zgradama. Odabrano je mjesto sjeverno od grada, ali u njegovoj neposrednoj blizini, na početku ceste koja je vodila put Solina, današnje Ulice Domovinskog rata. Općinsko upraviteljstvo raspisalo je koncem 1920. natječaj za gradnju prve zgrade namijenjene za smještaj Prizivnog suda. Ubrzo se pristupilo njezinoj gradnji, a kasnije i ostalih. U siječnju 1924. počelo je preseljenje pojedinih ureda, a uređen je i okolišs.

I zgrada u kojoj se nalazila pošta bila je u lošem stanju, s nedovoljno prostora, što je otežavalo poslovanje. Njezini uredi su bili u privatnoj zgradi pa je premještena u današnju Tončićevu ulicu. Tu je ostala gotovo 40 godina, ali ni ona s vremenom više nije odgovarala. Dugo se o tome raspravljalo, ali se rješenje stalno odgađalo. Konačno se u ožujku 1932. započelo $s$ gradnjom prvog dijela nove poštanske zgrade u Sinjskoj ulici, gdje je smještena telefonska centrala. Ostali dio Glavne pošte za potrebe ureda i građana sagrađen je s njezine južne strane u današnjoj Ulici kralja Tomislava. Otvoren je nakon mnogih godina čekanja i pregovaranja u kolovozu 1939. godine. Projekt je napravio Ante Barač.

Uređivale su se i gradile i druge upravne i poslovne zgrade. Podružnica osiguravajućeg društva „Croatia“ iz Zagreba sagradila je 1930. zgradu po projektu arhitekata Zlatibora Lukšića i Kuzme Gamulina na Klaićevoj poljani. U to vrijeme se rješavalo i pitanje zgrade Trgovačke i obrtničke komore. Ta ustanova u Splitu je osnovana još 1840. godine. Nalazila se u starom dijelu grada, ali kako se gospodarstvo razvijalo, ti prostori nisu više bili dovoljni. Stoga se 1927. prišlo nalaženju povoljnijeg smještaja. Tražila se moguća lokacija za novu zgradu. Bilo je više ponuda za terene pa i zgrada od strane privatnika. Izabrano je mjesto na Trumbićevoj obali jer je bilo na istaknutom položaju u odnosu na ostale ustanove u gradu. Godine 1929. raspisan je opći natječaj za idejnu skicu zgrade. Na čelu ocjenjivačkog suda bio je Juraj Duboković, predsjednik Komore. Prispjelo je ukupno deset radova s dosta sličnim rasporedom. Prva nagrada dodijeljena je arh. Fabjanu Kaliterni. Po njegovom projektu je zgrada izvedena, a on je vršio i nadzor gradnje. Licitacija za izvedbu upriličena je 1930. Najpovoljnija je bila ponuda poduzetnika ing. Žarka Deškovića pa je njemu ustupljen posao, koji je u potpunosti završen 1931. godine. U prizemlju je smješten trgovački muzej, na prvom, drugom i trećem katu uredske prostorije, a na četvrtom stanovi. Straga je kao aneks bila dvorana za skupove. Zbog izgrađenosti okoliša i uske parcele zgrada je imala samo jedno bolje obrađeno pročelje na jugu prema moru. Sagrađeno je od bijelog bračkog kamena i u arhitektonskim elementima balkona i otvora nadahnuto tradicionalnim programom. ${ }^{12}$

12 Stanko Piplović, „Izgradnja Doma Obrtničke i trgovačke komore u Splitu u kontekstu nastupa moderne“, Kulturna baština, 40/2014., 191-201. 


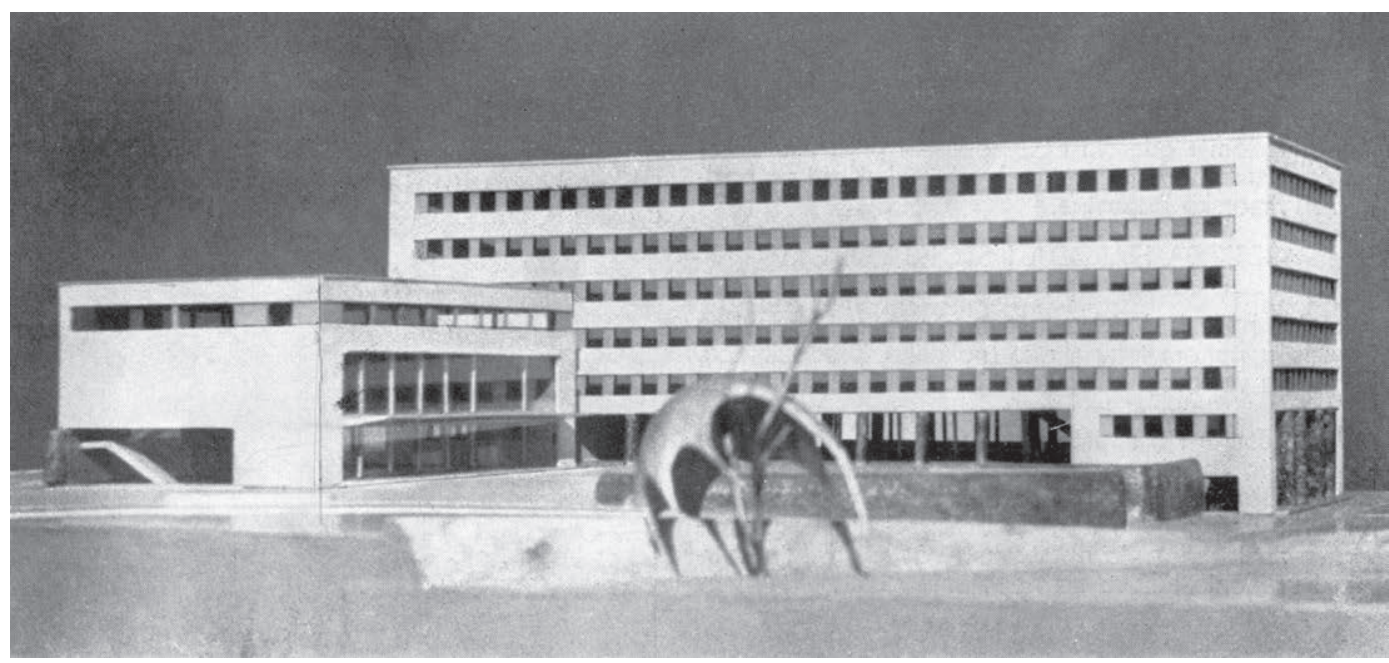

Sl. 2. Palača Primorske banovine na zapadnoj obali. Projekt zagrebačkih arhitekata Nikole Despota, Vida Vrbanića i Vladimira Turine.

Slijedila je 1933. zgrada Penzionog zavoda u Hrvojevoj ulici autora arh. Vladimira Šubica iz Ljubljane i 1935. palača Burze rada u Zrinsko-frankopanskoj ulici, koju je projektirao arh. Helen Baldasar. Konačno je 1939. sagrađena Bratimska blagajna na Bačvicama po projektu Emila Cicilijanija. ${ }^{13}$

Osnivanjem Primorske banovine sa sjedištem u Splitu 1929. odlučeno je podignuti palaču za Bansku upravu. U početku je bilo određeno državno zemljište na istočnom kraju Rive, gdje su nekada bili lazareti. U srpnju 1930. raspisan je natječaj za idejno rješenje. Odazvalo se 28 natjecatelja, ali rezultati nisu zadovoljili. Zatim je upriličen uži natječaj povjeren Ivanu Meštroviću i zagrebačkom arhitektu Edi Šenu. Potom je arh. Drago Ibler prema izrađenoj skici trebao izraditi novi projekt.

Međutim, u javnosti i među stručnjacima zamjeralo se da bi velika građevina na tom mjestu zaklonila vidik s mora na južno pročelje Dioklecijanove palače. U raspravama se došlo do zaključka da Palaču treba graditi izvan središta grada. Odabrana je nova lokacija na zapadnoj obali luke. Raspisan je natječaj pa je usvojen projekt arh. Nikole Despota i suradnika. S gradnjom se počelo u travnju 1938. godine. Radovi su povjereni poduzeću ing. Žarka Deškovića, a useljenje je uslijedilo u rujnu 1940. godine. ${ }^{14}$

U Splitu je bilo nekoliko novčanih zavoda koji su trebali bolje uvjete poslovanja. Tako je na početku Velog Varoša u Ulici bana Jelačića 1925. sagrađena trokatnica Ševeljević u koju je uselila Hipotekarna banka. Godine 1930. nadograđena je i preuređena zgrada Pučke dalmatinske banke, koja se nalazi usred Rive.

I ustanove kulture trebale su bolje uvjete rada. Tijekom 1928. obnovljeni su gledalište, atrij, prostorije za glumce i hodnici zapuštenog Općinskog kazališta na Dobrome. Po-

\footnotetext{
13 Slavko MulJAčcć, „Kronološki pregled izgradnje Splita u XIX. i XX. stoljeću“, Zbornik Društva inženjera i tehničara Splita (ur. Slavko Siriščević), Split 1958., 82-88.

14 D. TušEK, Arhitektonski natječaji u Splitu 1918-1941., 97-100.
} 
pravljen je namještaj i rasvjeta. Pozornica je tehnički uređena 1940. godine. Planirala se i gradnja Glazbenog doma na prostoru južno od Peristila. Pripreme su počele još 1934., ali zgrada nije podignuta.

Sagrađene su i zgrade za muzeje. Građevinski radovi za novi Arheološki muzej na Skalicama bili su uglavnom gotovi 1914. Počele su pripreme za preseljenje izložaka iz stare zgrade na Pazaru, ali je izbio rat. Poslovi su nastavljeni tek nastupom mira pa je ustanova 1922. otvorena za posjetitelje. O osnivanju Prirodoslovnog muzeja raspravljalo je Općinsko vijeće 1924. godine. Za to se posebno zauzimao profesor Umberto Girometta. U početku su zbirke bile smještene u novom općinskom domu, ali tamo uskoro nije bilo više dovoljno prostora. Odlučeno je da se u tu svrhu preuredi općinska zgrada na prvom vrhu Marjana u gustoj borovoj šumi. Radilo se o secesijskoj zgradi koju je projektirao ing. Petar Senjanović, a sagrađenoj početkom 1914. Radovi za novu namjenu trajali su pet mjeseci po nacrtu ing. Lovre Manole. Svečano otvorenje upriličeno je 1928. godine. Uz muzej je izgrađen i zoološki vrt. ${ }^{15}$

Godine 1925. održana je u Splitu velika Jadranska izložba, na kojoj je pomorstvo zauzimalo vidno mjesto. To je pobudilo ideju o otvaranju stalne postave o moru. Organizaciju je preuzela udruga Jadranska straža. Odlučeno je podignuti muzejsku zgradu. Općina je ustupila zemljište na Zapadnoj obali. Za radove je odobren kredit. U ljeto 1928. raspisan je opći natječaj za izradu nacrta. U ocjenjivačkom su sudu bili predsjednik dr. Ivo Tartaglia, četiri člana i njihovi zamjenici. Pristiglo je pet prijedloga, ali oni nisu zadovoljili. Stoga je rok produžen do 1 . prosinca. Tada su prispjela 33 nacrta. Prva nagrada nije dodijeljena, a druga je pripala arh. Dujmu Graniću iz Beograda. U istom sklopu predviđen je i dom Jadranske straže, koji je građen u nekoliko etapa.

Kipar Ivan Meštrović je odlučio preseliti se iz Zagreba u Split i u Mejama sagraditi palaču s ateljeom i galerijom. U izradi projekta sudjelovao je arhitekt Harold Bilinić, glavni i dugogodišnji suradnik na njegovim arhitektonskim objektima. ${ }^{16}$ Radovi su se otegli i bili završeni tek 1939. Zgrada je reprezentativno koncipirana u duhu klasicizma s širokim prilaznim stepeništem, trijemom s kaneliranim jonskim stupovima i simetričnim bočnim krilima. Zatim je nedaleko od Galerije prema moru Meštrović kupio ruševine utvrđenog kaštela Capogrosso s početka 16. stoljeća. Tu je 1941. izveo znatne građevinske radove. Sklop se sastoji od crkve sv. Križa, gdje je kipar postavio svoje drvene reljefe s prikazom Isusovog života. S njezine zapadne strane uređeno je dvorište $s$ trijemom na dorskim kamenim stupovima i bunarom po sredini. ${ }^{17}$

15 Stanko Piplović, „Osnivanje i izgradnja prvih muzeja u Splitu“, Naš museum (ur. Josip Balabanić), Zagreb 1998. 122-124.; Robert Plejić, „Arhitektonski opus Petra Senjanovića“, Petar Senjanović (ur. Robert Plejić), Split 2007., 138.

16 Stanko Piplović, „Arhitekt Harold Bilinić“, Hrvatska obzorja, 2/1994., br. 4, 847-850.

17 Jasminka BabIĆ, Arhitektonski nacrti galerije Ivana Meštrovića u Splitu, Split 1999., 3-5; Maja ŠEparović PaLada, Meštrovićeve Crikvine, Split 2012., 58-67. 


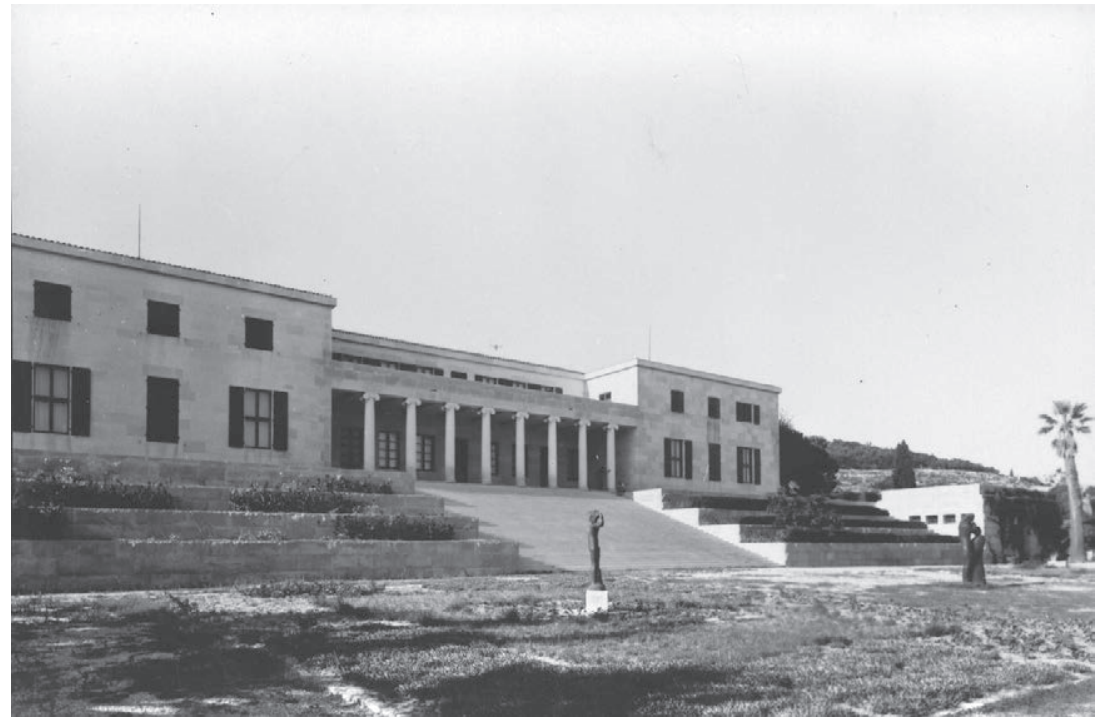

Sl. 3. Galerija Ivana Meštrovića na Mejama. Projekt Ivana Meštrovića, arh. Harolda Bilinića i arh. Lavoslava Horvata.

Bilo je i ideja za gradnju objekata kulture koje nisu ostvarene. Htjelo se 1929. preurediti općinsku zgradu južno od Peristila za Narodni muzej i Gradsku galeriju, a 1940. zagovaralo se gradnju Doma umjetnosti uz novu Bansku palaču.

\section{ZDRAVSTVENE USTANOVE}

Uvjeti zdravstvenog zbrinjavanja građana i stanovnika iz široke okolice bili su vrlo teški. U gradu je na venecijanskom bastionu Cornaro iz 17. stoljeća postojala stara zgrada bolnice, otvorena 1794. Ona veličinom ni opremom više nije zadovoljavala, a usto je bila smještena u samom središtu Splita. ${ }^{18}$ Planirala se gradnja novog kompleksa. Određena mu je lokacija na Firulama, u polju istočno od grada. U travnju 1930. raspisan je pozivni natječaj, ali nije poslužio za gradnju. ${ }^{19} \mathrm{U}$ Tehničkom odjeljenju Banske uprave napravljen je projekt za osamnicu, koja je dovršena 1933. istovremeno s nekim gospodarskim objektima. Za tu zgradu kirurškog paviljona naručen je projekt arh. Lavoslava Horvata. S prekidima se gradio od 1936. do $1940 .{ }^{20}$ Radovi su nastavljeni i nakon rata.

Higijenski zavod imao je sjedište u Trogiru. Godine 1930. premješten je u Split, gdje su mogućnosti za rad na području narodnog zdravlja bile mnogo veće. Cilj je bio ispitivanje zaraznih bolesti i njihovih izvora te sprečavanje epidemija. U tu svrhu trebalo je sagraditi zgradu, za što je iduće godine odobren kredit. Lokacija je određena na kraju današnje Vukovarske ulice, tada još izvan grada. Nacrt arh. Ante Barača izrađen je u Tehničkom odje-

\footnotetext{
18 Duško KečKemet, Stara splitska bolnica, Split 1964., 10-25.

19 „Izgradnja nove bolnice“, Novo doba (Split), br. 276, 27. 11. 1930., 6.

20 Zrinka Paladino, „Djelovanje arhitekta Lavoslava Horvata u Splitu“, Kulturna baština, 37/2011., $195-196$.
} 
ljenju Banovine. Radovi su ustupljeni poduzeću Jerka Ferića pa su započeli koncem 1932. i završeni iduće godine. ${ }^{21}$

\section{ZnANSTVENE USTANOVE}

Za nove znanstvene ustanove koje su se osnivale također je trebalo podignuti zgrade. Još je prije 1914. JAZU u Zagrebu potakla osnutak biološke stanice na primorju. Nakon 1918., dogovorom između nadležnih ministarstava i Srpske kraljevske akademije u Beogradu, zaključeno je da se ustanovi Oceanografsko-biološki institut, ustanova za proučavanje mora. Posebno povjerenstvo razmotrilo je više lokacija za gradnju pa je konačno odlučeno da to bude u Splitu i to na rtu brda Marjana. Općina se obvezala besplatno ustupiti zemljište, izgraditi pristupnu prometnicu te provesti instalacije do zgrade.

Godine 1930. raspisan je uži natječaj za izradu nacrta zgrade. Pristiglo je pet radova. Izabrano je rješenje arhitekta Fabjana Kaliterne. Kako se ne bi čekalo da ustanova počne $s$ radom tek kada nova zgrada bude dovršena, odlučeno je da se uredi privremena stanica u istočnom krilu Schillerova „Pensiona Split“ na Mejama. Tu je bilo na raspolaganju šest prostorija odvojenih od ostalog dijela zgrade. Prvog dana mjeseca studenoga otvorene su privremene prostorije. Do 1933. godine sagrađena je nova glavna zgrada, ali se kasnilo $s$ unutrašnjim uređenjem pa se Institut uselio tek 1941. godine. Sklop je nadopunjen pomoćnim zgradama za prehranu i stanovanje tako da su osigurani svi uvjeti za znanstveni rad.

Sve složenije prilike tražile su da se na jadranskoj obali uredi meteorološka služba. Još prije rata postojalo je nekoliko stanica za motrenje, ali su kasnije zapuštene, što je postalo veliki problem. Službu je trebalo iznova organizirati i to na kvalitetniji način. Analize su pokazale da bi postaja najbolje funkcionirala na srednjem Jadranu. Izabran je Split. Tako je na prvom vrhu Marjana podignuta zgrada Meteorološkog opservatorija. Njezino vođenje je povjereno profesoru Eraldu Marchiju. Zadaci nove ustanove su bili registriranje vremenskih podataka, izdavanje dnevnih izvještaja, objavljivanje prognoze, obrada klimatologije Splita u okviru međunarod-

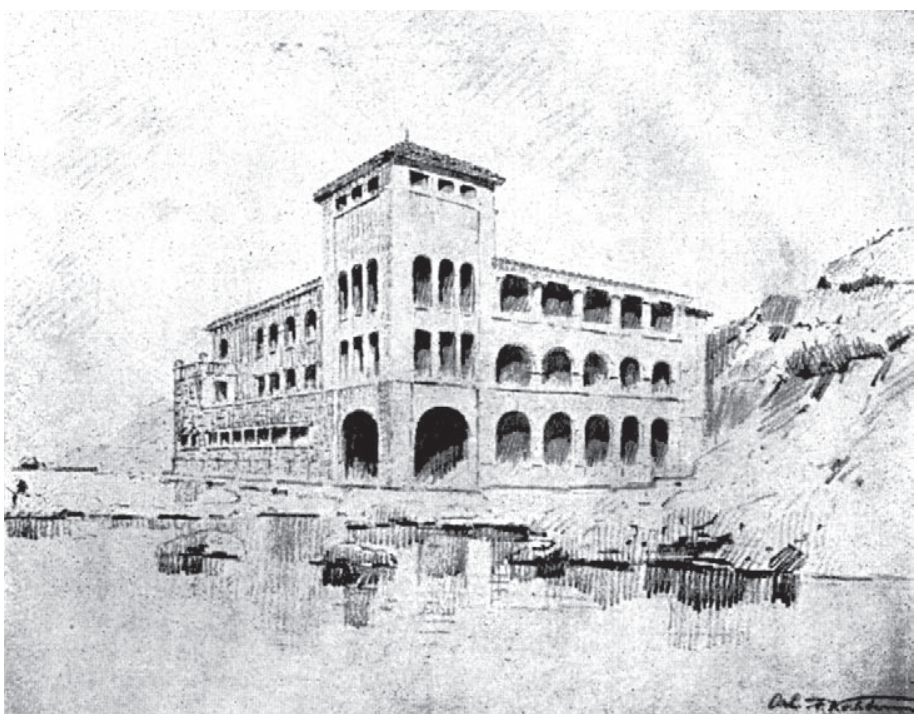

Sl. 4. Oceanografski institut na rtu Marjana. Varijanta projektnog rješenja arh. Fabjana Kaliterne.

$\overline{21}$ „Gradnja Higijenskog Zavoda u Splitu“, Novo doba (Split), br. 72, 27. 3. 1931., 5. 
ne službe i rad na seizmici. Projekt zgrade i namještaja napravio je općinski inženjer Josip Kodl. Radove je 1926. izvelo građevinsko poduzeće ing. Lovre Krstulovića. Svečano otvorenje je upriličeno 1. prosinca. Zgrada je posebno zanimljiva zbog novog konstrukcijskog okvirnog sustava izvedenog u armiranom betonu. To je bila novost za ovaj kraj koja je činila važnu kariku u prodoru suvremene moderne europske misli u graditeljstvu.

\section{USTANOVE SOCIJALNE SKRBI}

Smirivanjem prilika počela je sustavnija socijalna politika. Na tome je radio Okružni ured Ureda za osiguranje radnika. Za to je 1925. podignuta zgrada u Svačićevoj ulici. U njoj su smješteni mjesni okružni ured s ambulantama, ekspozitura za Dalmaciju Penzionog zavoda u Ljubljani, Radnička komora za Dalmaciju i Berza rada.

Za potrebe socijalnih i karitativnih djelatnosti podignuta je iste godine zgrada Okružnog ureda za osiguranje radnika u Svačićevoj ulici. Daljnjim gospodarskim razvitkom Dalmacije, posebno Splita, povećavao se broj osiguranika.

Penzioni zavod u Ljubljani imao je filijalu u Splitu. Bavila se osiguranjem privatnih namještenika u Dalmaciji. Zavod je prema statutu morao ulagati dio sredstava u nekretnine. Stoga je 1929. godine pribavljeno zemljište u Hrvojevoj ulici. Na njemu je 1933. podignuta peterokatna zgrada. Projektirao ju je arh. Vladimir Šubic iz Ljubljane. ${ }^{22}$

U državi, pa i u Splitu, bio je velik broj nezaposlenih radnika. Skrb za njih povjerena je posebnom uredbom iz 1927. Središnjoj upravi rada i njezinim Javnim berzama rada. ${ }^{23}$ Zadatak im je bio posredovati u radnim odnosima. U to vrijeme otvoren je i ured u Splitu. Trebalo je osigurati podizanje zgrade za njegov smještaj te za smještaj Radničkog azila

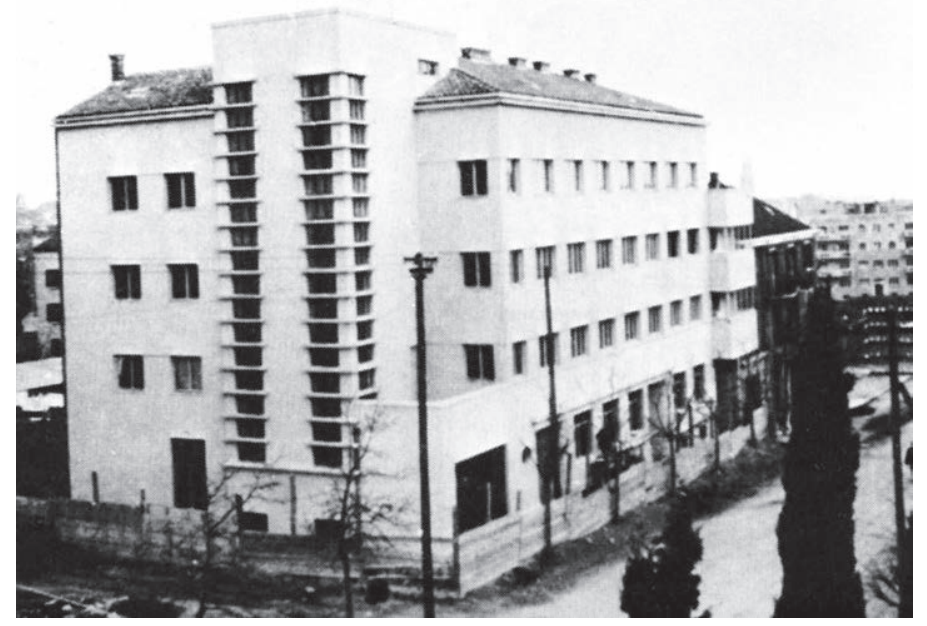

Sl. 5. Burza rada u Zrinsko-frankopanskoj ulici. Projekt arhitekata Helena Baldasara i Emila Cicilijanija. 
i Iseljeničkog doma. Pitanje se dugo razmatralo. Konačno je određena lokacija u Zrinskofrankopanskoj ulici pa je 1933. raspisan natječaj za idejno rješenje. Prva nagrada nije dodijeljena, a drugu je dobio Lavoslav Horvat. Radovi su završeni 1935., a ustanova je počela raditi početkom iduće godine.

Glavna bratimska blagajna, socijalna ustanova rudarskih radnika, odlučila je 1935. u Splitu sagraditi zgradu radi boljeg iskorištavanja fondova osiguranja. Otkupljeno je zemljište na Bačvicama. Zgrada je bila namijenjena uglavnom za stanovanje. ${ }^{24}$ I za njezin je projekt organiziran natječaj, s rokom predaje radova u rujnu 1937. Prva nagrada nije dodijeljena, a druga je podijeljena između Emila Cicilijanija i Ante Mačeka. Prihvaćen je Cicilijanijev prijedlog. Zgrada je useljena 1938. godine. Njezino rješenje je vrlo uspješno u pogledu vještog spajanja tradicionalnih i suvremenih elemenata.

Radnici su bili u vrlo nepovoljnom položaju. Dnevnice su im bile male, bilo ih je mnogo bolesnih, a nesreće na poslu česte. Kako bi se doprinijelo poboljšanju prilika, koncem 1937. odlučeno je izgraditi Dom radničke komore na Lovretu. Zgrada je završena i svečano otvorena u kolovozu 1937. To je postalo sastajalište radnika, mjesto gdje su se držali skupovi i priredbe.

Osim ovih organizirane su i druge ustanove za poboljšanje životnih uvjeta ljudi. Takvo je bilo udruženje Hrvatski radiša, koje se zalagalo za kulturno i gospodarsko uzdizanje podmlatka. Planirana je i gradnja doma koji je zapravo trebao biti internat za šegrte sa sela. Nacrt je besplatno napravio ing. Petar Jozević za mjesto u predjelu Lovret. Općina je ustupila zemljište. Prikupljala su se i sredstva građana za fond gradnje. Gradnja je trebala početi 1940., ali su nedostatak novca i početak rata spriječili taj naum.

Za siromašne građane postojala je ubožnica u Velom Varošu, ali prostorije nisu bile prikladne. U svibnju 1920. Općinsko vijeće odlučilo je prodati kuću i vrt pa dobivenim sredstvima urediti dio franjevačkog samostana u Poljudu. Tako su u gradu bile dvije ubožnice, posebno za žene i posebno za muškarce. Da bi se uvjeti smještaja poboljšali, a broj mjesta čak i povećao, početkom 1940. raspisana je licitacija za gradnju pa su radovi već u prosincu privedeni kraju.

\section{GOSPODARSKI OBJEKTI}

Zbog povoljnog geografskog položaja Splita i obilja vodenih tokova u okolici za proizvodnju električne energije gradu se proricala svijetla budućnost. Zagovarao se industrijski razvitak, ali je nedostajao kapital. Od svih grana najvažnije su bile proizvodnja cementa i pomorstvo. Godine 1921. preuređena je klaonica pa je zadovoljavala u higijenskom pogledu, ali joj položaj u gradskoj luci više nije bio prikladan. Rješenje je nađeno kada je privatna tvrtka Mitrović sagradila u Lori blizu mora na sjevernoj strani grada modernu klaonicu i tvornicu za preradu mesa. Tako su se postupno otvarali novi obrtnički pogoni. Na Manušu je 1923. izgrađena velika mehanička radionica, a 1930. izgrađena je tvornica likera.

$\overline{24}$ Vjekoslav Levš, „Zgrada glavne bratimske blagajne u Splitu“, Glasnik Primorske banovine, 1/1938., br. 5, 53-54. 
U takvim dinamičnim prilikama osnivano je društvo koje je radilo na podizanju brodogradilišta. Najprije su otkupljena dva manja škvera, a zatim je na Glavičinama na sjevernoj obali splitskog poluotoka sagrađeno brodogradilište Split. Svečano je otvoreno u listopadu 1932. godine.

$\mathrm{Na}$ širem području Splita, od Trogira do Makarske, nalaze se bogata nalazišta lapora, prirodne sirovine za proizvodnju cementa. Dobar mineraloški sastav i pogodne luke za transport uvjetovale su da je u tom kraju podignuto više tvornica. U njima je bio zaposlen veliki broj radnika. U poslijeratnom gospodarstvu Splita ta industrija je, povećanjem potražnje cementa, zauzela vidno mjesto. Na zapadnoj obali luke radila je jedna od tvornica. Osim toga, istočno od grada otvoreni su veliki tupinolomi u kojima se kopala sirovina za proizvodnju cementa u mjesnim tvornicama ili se kao sirovina izvozila morskim putem u druge zemlje. ${ }^{25}$

Promet u gradskoj luci stalno je rastao. Zato se ubrzo počela javljati potreba za javnim skladištima u kojima se trebalo pohranjivati robu uz bolje organizirano čuvanje i pretovar. Pitanje se rješavalo dosta sporo i to iz birokratskih i novčanih razloga. Konačno je 1929. na prijedlog Ministarstva trgovine i Ministarstva financija odlučeno graditi tranzitna i carinska skladišta. Određeno je mjesto na Gatu sv. Duje na istočnoj strani luke. Ponovno je došlo do zastoja pa su građevinski radovi završeni tek koncem 1936. Nakon toga se nastavilo s ugradnjom opreme i instalacija te uređenjem okoliša. To se produžilo još dvije godine, ali je Split naposljetku dobio važan gospodarski objekt.

\section{UGOSTITELJSKI I TURISTIČKI OBJEKTI}

Koncem 19. stoljeća počeo se na jadranskoj obali intenzivnije razvijati turizam. Rat je prekinuo taj razvoj i tek je 1922. nakon normalizacije prilika broj stranih gostiju počeo rasti, posebno onih iz Čehoslovačke. Iduće godine osnovano je u Splitu Društvo za saobraćaj putnika i tvrtka „Putnik“. Međutim, nedostajale su zgrade za prikladan smještaj turista. Osim manjeg broja skromnih hotela u gradu je postojao i Schillerov „Pension Split“, smješten na Mejama, uz more, $s$ južne strane Marjana. ${ }^{26}$ Problemom nedostatka smještaja za turiste bavilo se više arhitekata, pa i strane korporacije. ${ }^{27}$ Bilo je i dosta neostvarenih prijedloga. S vremenom su se naumi počeli ostvarivati. Na jesen 1921. sagrađen je na Bačvicama trokatni hotel „Imperijal“, u vlasništvu Ante Dvornika, za koji su nacrt napravili arhitekti Vjekoslav Ivanišević i Fabjan Kaliterna. ${ }^{28} \mathrm{U}$ blizini se nalazio hotel „K belom orlu“, sagrađen početkom 20. stoljeća, koji je izgorio 1925.

\footnotetext{
25 Stanko Piplović, „Cementna industrija u Dalmaciji nakon Prvog svjetskog rata“, XVII. savjetovanje o tehničkim dostignućima i proizvodnji cementa (ur. Petar Žižić), 2. sv., Split 1997., H-3-10.

26 „Pension Split“, Novo doba (Split), br. 87, 14. 4. 1923., 7.

27 Slavko Muljačcć, „Historijat izgradnje priobalnog pojasa u splitskoj luci, od Matejuške do Sustipana (1850-1960)“, Urbs, 3/1959.-1960., 60.

28 „Hotel na Bačvicama“, Novo doba (Split), br. 208, 14. 9. 1921., 4.
} 
Poznati splitski hotelijer Matić temeljito je 1926. godine obnovio svoj hotel „Central“ na Narodnom trgu. Proširio je njegovu kavanu i uveo kupaonice uz sobe. ${ }^{29}$ Bilo je dosta interesa za gradnju ugostiteljskih zgrada. Isti hotelijer otvorio je 1931. na Bačvicama u blizini kupališta u vili „Rozina“ hotel koji je dobro poslovao. Pored domaćih, javljale su se i strane korporacije iz Njemačke i Švicarske kao potencijalni investitori. Početkom 1934. temeljito je preuređen hotel „Bellevue“ na Rivi. Ugrađen je lift, uvedeni centralno grijanje i ventilacija, proširena kavana. ${ }^{30}$ Kako bi se unaprijedilo poslovanje i poboljšale usluge turistima, sagrađena je na početku Gata sv. Petra prizemna zgrada Carinske pregledavaone i i putničkog ureda. Zatim je nad njezinim istočnim dijelom 1929. nadograđen kat za upravu po projektu arhitekata Fabjana Kaliterne i Alfreda Kellera.

Godine 1932. osnovano je u Splitu Jugoslavensko hotelsko društvo, koje je tražilo lokaciju na Matejuški za gradnju hotela. Gradska vlast je zahtjev odbila. Oko toga su se u javnosti razvile burne rasprave. Ipak, sredinom iduće godine raspisan je natječaj na koji je prispio 31 rad. Nijedan nije odgovarao pa prva nagrada nije dodijeljena niti je ijednom autoru ponuđena razrada elaborata. Nasuprot tomu, u listopadu je investitor zatražio ponudu za izradu urudžbenog nacrta, statičkog računa, tehničkog opisa te detaljnih planova i izradu likvidacijskog elaborata. Posao je povjeren Josipu Kodlu uz preuzimanje elemenata nekih nagrađenih projekata. Stoga oko autorstva postoje prilične nejasnoće. Napokon je 1935. na nasutom zemljištu uz more na početku Zapadne obale započela izgradnja hotela „Ambasador“. Svečano otvorenje bilo je 1. kolovoza 1937. Zgrada hotela gabaritom i vanjskim izgledom dobro se uklopila u sliku tog dijela luke. Ona je značajno kulturno ostvarenje moderne u Splitu. ${ }^{31}$

U gradu je nedostajalo hotela koji bi komforom zadovoljavali zahtjevnije, posebno strane goste. Postojeći su uglavnom bili starije zgrade preuređene za ugostiteljstvo. Premda su se vlasnici trudili da ih urede, rezultati su bili skromni. Ipak je dosta toga učinjeno. Osim već spomenute obnove hotela „Bellevue“, preuređeni su i hoteli „Central“, „Sava“ i „Slavija“ te još nekoliko manjih.

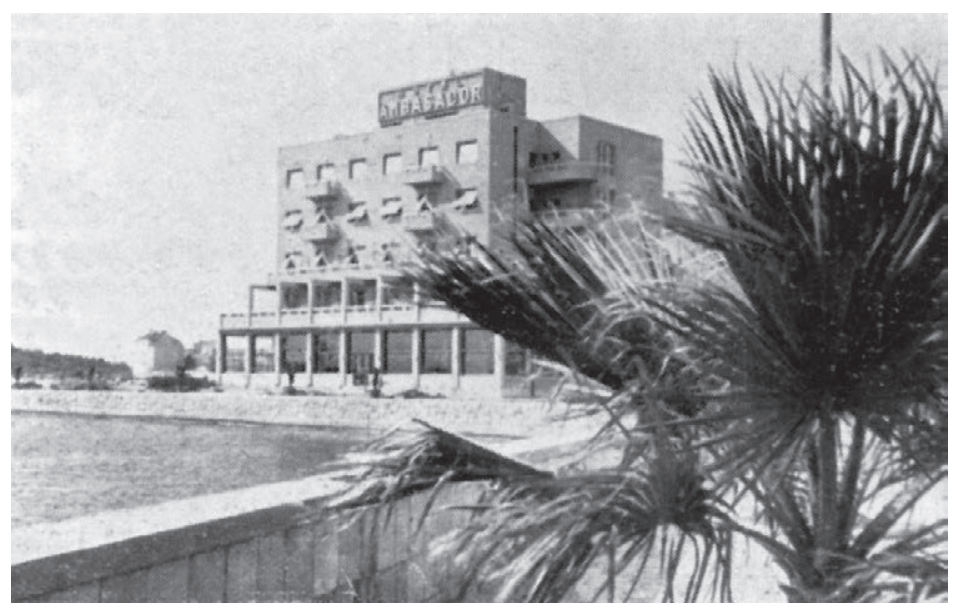

Sl. 6. Hotel „Ambasador“ na zapadnom kraju Rive. Projekt arh. Josipa Kodla.

\footnotetext{
Sanja Buble, „Hotel Central na splitskoj Pjaci“, Kulturna baština, 40/2014., 234.

„Restauriranje Hotela 'Bellevue'“, Novo doba (Split), br. 4, 5. 1. 1934., 3.

31 Ambroz Tudor, „Hotel Ambasador, mjesto i zgrada“, Kulturna baština, 21/1999., br. 30, 294-309.
} 


\section{Obrazovne institucije}

Gradnja školskih zgrada bilo je iznimno značajno pitanje. Osim za Mušku realnu gimnaziju u Splitu nije podignuta nijedna druga namjenska školska zgrada. Kuće u kojima su se nalazile osnovne škole bile su u lošem stanju. Tijekom 1927. raspisan je natječaj za projekte pučkih škola u predjelima Veli Varoš i Lučac. Za školu Varoš nađeno je prikladno zemljište u današnjem Nazorovom prilazu. Projekt su napravili ing. Aleksandar Freudenreich i ing. Pavao Deutsch. U lipnju 1928. održana je licitacija za gradnju. ${ }^{32}$ Sredinom 1930. izgrađena je zgrada muške i ženske pučke škole za predgrađa Manuš i Dobri po projektu arh. Josipa Kodla. ${ }^{33}$

Još u vrijeme austrijske uprave školstvo u Splitu je bilo prilično dobro razvijeno, ali su zgrade srednjih škola postale $s$ vremenom tijesne i bile su u lošem stanju. Broj učenika je stalno rastao pa je trebalo sagraditi nove. Nakon dužih nastojanja u tome se uspjelo. Odlučeno je graditi zgradu za Mušku klasičnu gimnaziju i Žensku realnu gimnaziju. Općina je stavila na raspolaganje zemljište u Spinutu. Banska uprava raspisala je u travnju 1936. natječaj za idejno rješenje na koji su pristigla su 34 rada. Ni prva ni druga nagrada nisu dodijeljene, a treća je pripala zajedničkom projektu Helena Baldasara i Emila Cicilijanija. Budući da nijedan nije u potpunosti udovoljio, odlučeno je da

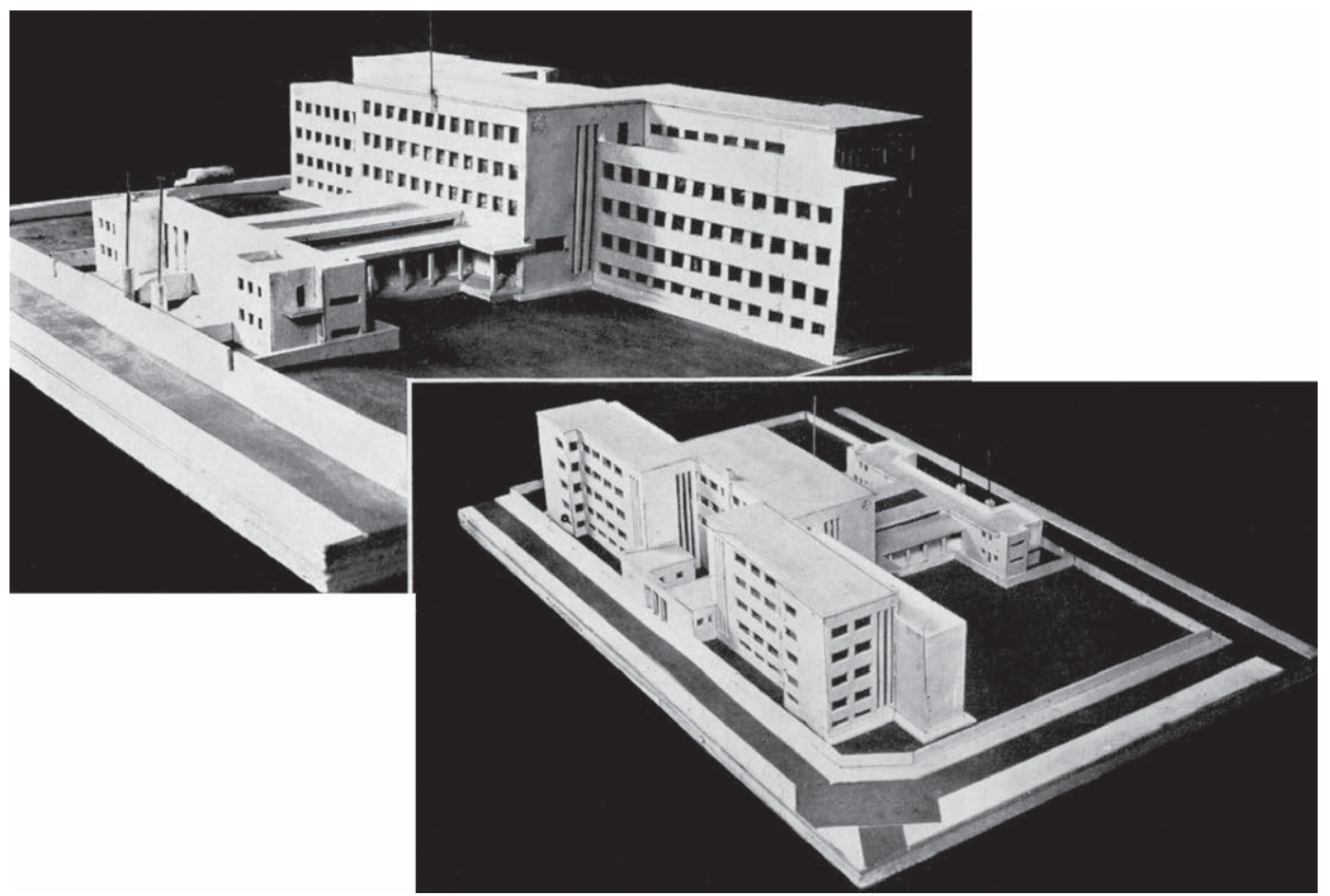

Sl. 7. Nova zgrada gimnazije u Spinutu. Projekt arh. Emila Cicilijanija.

\footnotetext{
32 „Gradnja pučke škole u V. Varošu“, Novo doba (Split), br. 150, 26. 6. 1928., 4; Niko ArmadA, „Rezultat natječaja i ocjenjivanja juri-a za projekte pučkih škola u Splitu“, Novo doba (Split), br. 227, 13. 9. 1928., 5.

33 „Otvorenje škole Manuš- Dobri“, Novo doba (Split), br. 207, 6. 9. 1930., 6.
} 
se konačni projekt izradi u Tehničkom odjeljenju Banske uprave. To je bilo učinjeno u listopadu. Kod ustupanja izvođenja radova nastale su velike komplikacije. Koncem 1937. raspisana je licitacija, ali se nijedan poduzetnik nije javio pa se ona u više navrata morala ponavljati. ${ }^{34}$ Nakon višemjesečnog odugovlačenja gradnja je započeta i dovršena tek 1940. godine.

\section{VJERSKE GRAĐEVINE}

Kroz razdoblje između ratova u Splitu je sagrađeno nekoliko crkava, a neke su pregrađene. Za novima nije bilo većih potreba jer ih je već postojao veliki broj, naročito u središsnjim dijelovima grada, a u novim predjelima vjernike su zadovoljavale samostanske crkve.

Odavno je zaključeno da katedrala, bivši carski mauzolej, nije dovoljno prostrana primiti sve ljude koji su željeli prisustvovati bogoslužjima. Stoga se planirala gradnja nove, naročito u 19. stoljeću. U tu su se svrhu tražile povoljne lokacije i crtali projekti. ${ }^{35}$ Prva zamisao je bila graditi u produženju postojeće prema istoku. Osnovano je i posebno društvo koje se bavilo organizacijskim i tehničkim pitanjima, a prikupljala su se i novčana sredstva. ${ }^{36} \mathrm{Dje}-$ lovanje u tom smislu nastavljeno je i poslije rata. Biskup Juraj Carić se 1920. godine založio za raniji prijedlog Frane Bulića da se gradi u blizini postojeće katedrale južno do Peristila, ali to nije usvojeno. Predlagalo se da to bude na nekim drugim položajima izvan starog grada jer se uvidjelo da bi velika zgrada teško narušila srednjovjekovnu urbanu strukturu. Međutim, došao je rat pa ni u tom razdoblju nije ništa postignuto. Rješenje je nađeno tek u najnovije vrijeme. ${ }^{37}$

Najznačajnija je novogradnja bila Gospa od zdravlja na Dobrome. Na tom je mjestu samostan franjevaca uz koji je bila stara barokna crkva. Odlučeno je da se crkva sruši i na njezinom mjestu sagradi nova i veća. U kolovozu 1930. raspisan je natječaj za idejno rješenje. Prijedlozi su bili raznoliki i oblikovno su se kretali od romaničke bazilike do suvremenih rješenja. Nijedan nije odgovarao željama uprave samostana. Nakon dužih rasprava izabrano je rješenje arh. Lavoslava Horvata. Napravljeno je nekoliko inačica rješenja trobrodne bazilike i njezinog oblikovanja pa je prihvaćeno najjednostavnije, mirnog klasicističkog izraza. U travnju 1937. završeni su glavni radovi i crkva je posvećena, ali je još trebalo dovršiti unutrašnjost. ${ }^{38}$

Istočno od grada, na Pojišanu, nalazi se samostan i uz njega crkva Majke Božje. Skrb o svetištu preuzeli su početkom 20. stoljeća kapucini. U početku su se smjestili u nekadašnju kapelanovu kuću, ali ona ubrzo nije više zadovoljavala potrebama. Napravljena je nova zgrada samostana s južne strane crkve. I ona je postala tijesna pa se gvardijan Bernardin

34 „Licitacija za gradnju gimnazije“, Novo doba (Split), br. 256, 4. 11. 1937., 6.

35 Kamilo Tončić, Dioklecijanova palača i položaj nove katedralke u Splitu, Split 1907., 25-34.

36 Poziv i pravilnik družtva za gradnju nove stolne crkve u Splitu, Split 1915., 11-20.

37 Arsen Duplančıć, „Pitanje izgradnje nove katedrale u Splitu do II. svjetskog rata“, Kulturna baština, 14/1989., br. $19,126-130$.

38 Ante Crnica, Naša Gospa od zdravlja i njezina slava, Šibenik 1939., 455-468; Z. PALAdino, „Djelovanje arhitekta Lavoslava Horvata u Splitu“, 203-208. 


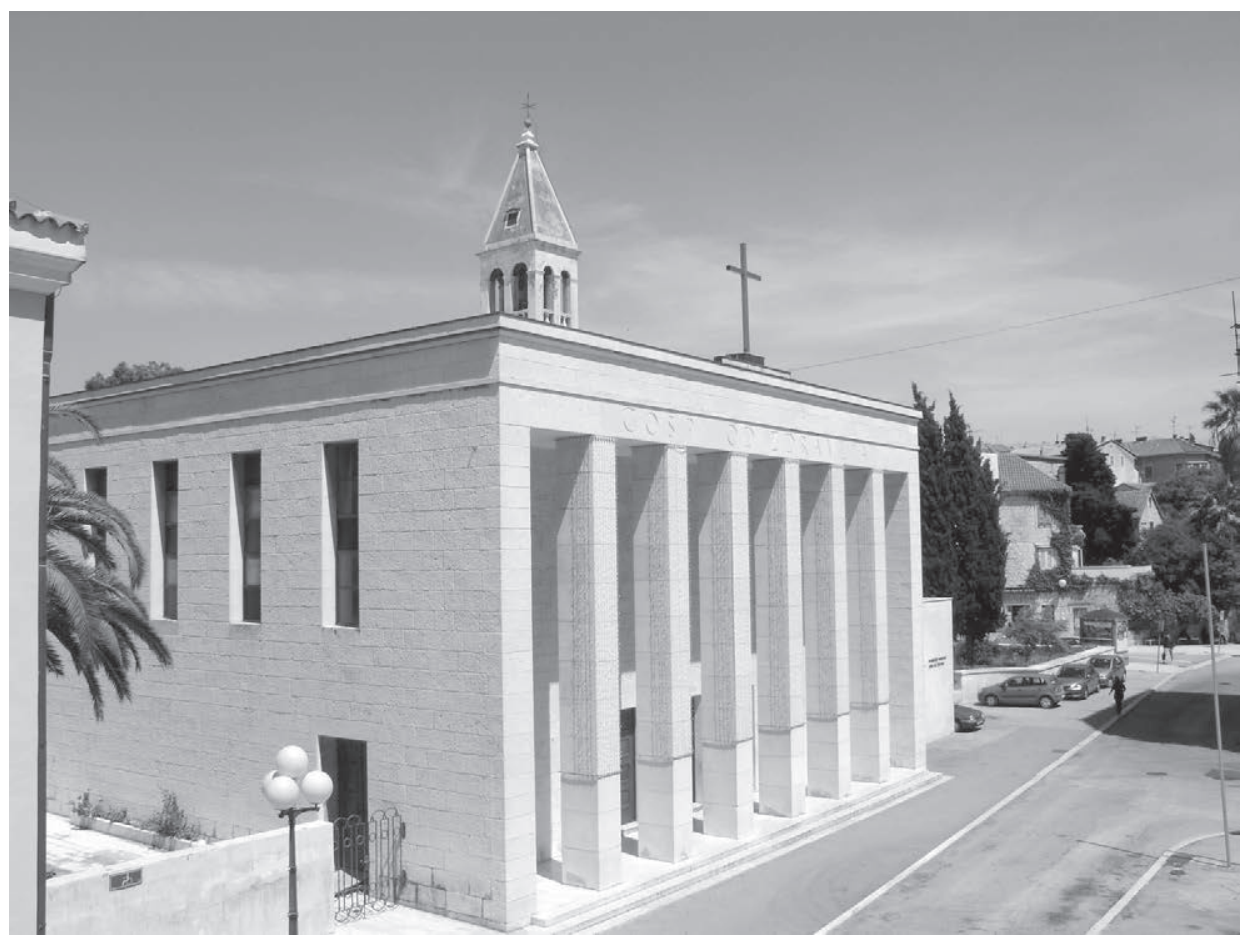

Sl. 8. Crkva Gospe od zdravlja na Manušu. Projekt arh. Lavoslava Horvata.

Škrivanić založio za nadogradnju drugog kata. Nacrt je besplatno napravio arh. Lavoslav Horvat, ali je izbila gospodarska kriza pa su banke zaustavile kreditiranje. Konačno se 1938. odlučilo ostvariti stari projekt. Preradio ga je arh. Fabjan Kaliterna. Siromašni redovnici nisu imali sredstava pa su se za gradnju prikupljala sredstva od građana. Radovi su završeni 1939. godine, na 30. godišnjicu preuzimanja svetišta. ${ }^{39}$

$\mathrm{Na}$ pazaru u središtu grada postoji dominikanski samostan i uz njega velika crkva. Godine 1931. arh. Kuzma Gamulin izradio je projekt za pregradnju kompleksa. Po tom prijedlogu trebalo je crkvu proširiti, izgraditi novi samostan, a u njegovom produžetku sa zapadne strane sagraditi stambenu zgradu. Zamisao je djelomično provedena. Samo je postojeća jednobrodna crkva proširena dodatkom bočnih brodova. Produžena je na istok iza glavnog oltara, a na sjevernoj bočnoj strani prigrađen joj je četvrtasti zvonik koji nije dovršen. Ostalo nije sagrađeno. Na osnovu raspisanog natječaja posao je ustupljen poduzeću Žarka Deškovića i izveden u vremenu 1932. - 1934. godine. ${ }^{40}$

Pregrađena je i proširena zgrada Nadbiskupskog sjemeništa u predjelu Spinut sjeverno od grada. Kako je broj pitomaca stalno rastao, njezin prostor više nije bio dovoljan. Potrebne su bile nove učionice, zbornica, knjižnica, kabineti, zbirke i spavaonice. Nakon dužih priprema započela je gradnja sjevernog krila u današnjoj Teslinoj ulici. Svi radovi su završeni

\footnotetext{
39 Stanko Piplović, „Recentne preobrazbe samostanskog kompleksa na Pojišanu“, Kapucinski samostan i svetište gospe od Pojišana u Splitu. Zbornik radova (ur. Arsen Duplančić), Split 2010., 382-391.

40 Franko Oreb, „Proširenje crkve sv. Dominika u Splitu od 1932-1934.“, Kulturna baština, 8/1982., br. 13, $125-129$.
} 
1931. godine. Novi dio je potpuno usklađen sa starim oblikovanjem vanjštine uz primjenu historicističkih elemenata. ${ }^{41}$

Kada je otvoreno novo groblje na Tršćenici, kasnije nazvano Lovrinac, na njemu nije bilo crkvice za pogrebne obrede. Ona ne postoji ni danas. U početku, dok nije sagrađena mrtvačnica, u tu svrhu je služila srednjovjekovna crkvica sv. Lovre, koja se nalazila dosta daleko u polju južno od groblja. Bila je zapuštena pa ju je trebalo urediti. Godine 1933. popravljeni su krov i pročelje, a unutrašnjost je oslikao freskama slikar Mate Meneghello.

Među vjerskim građevinama namjenom se izdvaja crkve Svetog Križa, koju je izgradio kipar Meštrović kao privatnik u svom kompleksu Kašteleta na Mejama. Osnovni mu je cilj bio kreiranje posebnog arhitektonskog okvira za prezentaciju vlastitih skulptura. Tome je prvenstveno služila i prigrađena crkva, dakle kao izložbena dvorana u kojoj su u posebnom cjelovitom aranžmanu izloženi njegovi reljefi u drvu. Sakralna funkcija bila joj je sekundarna.

Kako je nakon rata Zadar pripao Italiji, Bogoslovno učilište je iz tog grada premješteno u Split. U tu svrhu sagrađena je nova zgrada u Spinutu u produženju prema jugu postojeće zgrade Biskupskog sjemeništa. Radove je vodio poduzetnik Petar Mitrović i bili su završeni 1928. godine. Zgrada Biskupskog sjemeništa na tom mjestu bila je sagrađena još 1868. godine. Nastupom mira broj pitomaca je stalno rastao, osobito nakon što je toj ustanovi priznato pravo javnosti, pa su prostorni uvjeti života i rada postajali sve teži. Potrebne su bile nove učionice, zbornica, sobe za nastavnike, knjižnicu i kabinete te smještaj učenika. Stoga se počelo planirati izgradnju novoga sjevernog krila zgrade u današnjoj Ulici Nikole Tesle. Svi radovi su bili gotovi 1931. godine. ${ }^{42}$

Pravoslavni stanovnici imali su u gradu kapelu, ali su 1921. odlučili podignuti hram. Pregovori o tome počeli su 1928. godine. Odbor je imao zemljište sjeverno od grada, kod Biskupskog sjemeništa i namjeravao je započeti gradnju, ali je to mjesto planom bilo određeno za novu katoličku katedralu. Razmatrale su se i druge mogućnosti pa se došlo do rješenja da se gradi na mjestu ukinutog srednjovjekovnog samostana sv. Marije de Taurello. Godine 1935. organiziran je natječaj za idejnu skicu crkve sv. Save. Prva nagrada dodijeljena je Aleksandru Deroku, profesoru Tehničkog fakulteta Beogradskog univerziteta. Nasuprot tome konačni izmijenjeni projekt napravili su arhitekti Helen Baldasar i Emil Cicilijani. Crkva se počela graditi u njegovom dvorištu 1939. godine. Srušeni su ostaci starih zgrada na njegovom južnom dijelu i nastavljeno sa zidanjem do izbijanja Drugog svjetskog rata. Tada su prekinuti i nisu nikada završeni. ${ }^{43}$

U Splitu je bilo najviše katolika, ali i - doduše, u manjem broju - pripadnika drugih vjera. Oni su također željeli podignuti svoje bogomolje. Židovi su planirali gradnju monumentalne sinagoge. Za zgradu je 1921. nacrt izradio arh. Žagar. S obzirom da je 1929.

4 Stanko Piplović, „Zgrade sjemeništa i klasične gimnazije u Splitu“, 290 godina klasične gimnazije u Splitu 1700_ 1990. Zbornik radova (ur. Stanko Piplović), Split 1990., 178-182.

42 Ivan Ostojıć, Nadbiskupsko sjemenište u Splitu (1700-1790), Split 1971., 75-80; Stanko Piplović, „Građevine i dobra Splitskog Sjemeništa“, 300. obljetnica splitskoga sjemeništa i klasične gimnazije (1700.-2000.). Zbornik radova (ur. Ivan Banić), Split 2000., 297-301.

43 Zdeslav Perković, „Istraživanje samostana sv. Marije de Taurello“, Kulturna baština, 7/1981., br. 11-12, 55. 
nakon uspostavljanja Primorske banovine, koja je zauzimala i dio Bosne i Hercegovine, muslimanska vjerska zajednica pretpostavljala da će njihovi vjernici dolaziti u Split kao središte Banovine, smatrali su da bi im trebalo osigurati mjesto za vjerske obrede. Te zamisli nisu ostvarene.

U to vrijeme radilo se ponešto na brojnim starim crkvicama, a neke su i srušene jer su izgubile prvotnu svrhu. U povijesnom središtu uklonjene su crkvice sv. Ciprijana i sv. Jakova de Colonia, a popravljena sv. Martina iznad sjevernih vrata Dioklecijanove palače. Prenamijenjene su kapele na Peristilu uglavnom za turističke svrhe, a crkvica sv. Barbare iz 17. stoljeća na njegovom sjeveroistočnom dijelu uklonjena je 1923. godine. Slično se dogodilo i s nekim od brojnih malih slikovitih crkava raštrkanih po Marjanu. Godine 1919. bogoslužju je povraćena romanička crkva sv. Nikole. Dalje prema zapadu brda je crkvica Betlem na istaknutoj točci južne strane brda. Od davnina je potpuno zapuštena. Obnovljena je 1927. zaslugom Društva „Marjan“. Tako se postupalo i u težačkim predgrađima Velom Varošu i Lučcu te polju na istočnoj strani grada. ${ }^{44}$

\section{OBJEKTI ZA SPORT I REKREACIJU}

Prije rata u Splitu nije bilo komforno uređenih morskih kupališta. Nekoliko ih se nalazilo na obali gradske luke. Tek koncem 19. stoljeća, zbog izgradnje pomorskih pristanišnih objekata, počela su kupanja u prostranoj pješčanoj uvali tada pustog predjela Bačvica istočno od grada. ${ }^{45} \mathrm{U}$ to vrijeme su izgrađeni prvi objekti za kupače. Ubrzo su preuređeni i izgrađena je drvena zgrada s kabinama i platoima za sunčanje. $S$ vremenom je kupalište postalo premalo pa se u razdoblju 1925. - 1927. postupno dograđivalo. Kako su se Bačvice izgrađivale kao elitni stambeni predjel s vilama, turističkim i rekreacijskim sadržajima, trebalo je čitavu izgradnju planski osmisliti. Zbog toga je Općinsko upraviteljstvo 1924. godine odlučilo organizirati međunarodni natječaj za izradu urbanističkog plana. Namjera tada nije uspjela.

Zatim je početkom 1930. objavljen novi međunarodni natječaj za izradu projekta zgrade novog kupališta u uvali Bačvica te za uređenje obale prema istoku do Firula. Trebalo je oblikovati prostranu plažu, zgradu na njezinoj sredini i otvoreni bazen. Odazvala su se 23 arhitekta iz zemlje i inozemstva. Ocjenjivački sud na čelu s arh. Josipom Plečnikom s Tehničkog fakulteta u Ljubljani zaključio je da nijedan prijedlog nije u potpunosti udovoljio programu. Najbolje rješenje je ponudio arh. Nikola Dobrović, ali je ono bilo skupo. ${ }^{46} \mathrm{Nje}-$ mu je zatim povjerena razrada detaljnih planova kupališta. Vrijeme je prolazilo, a rješenja nije bilo. Odlučeno je jedino to da zgrada kupališta ne bude na dnu morske uvale već na njezinoj istočnoj strani. U Arhitektonskom odsjeku Gradskog poglavarstva napravljen je

\footnotetext{
$\overline{44}$ Stanko Piplović, „Radovi na splitskim crkvicama između dvaju svjetskih ratova“, Kulturna baština, 24/2002., br. 31, 311-346.

45 Goran BoRčćć, „O Bačvicama do kraja 19. stoljeća“, Bačvice raj na zemlji. Zbornik radova (ur. Zdenko Matošić), Split 2007., 16-29.

46 Nikola Dobrović, Urbanizam kroz vekove, sv. 1, Beograd 1950., 159-161.
} 


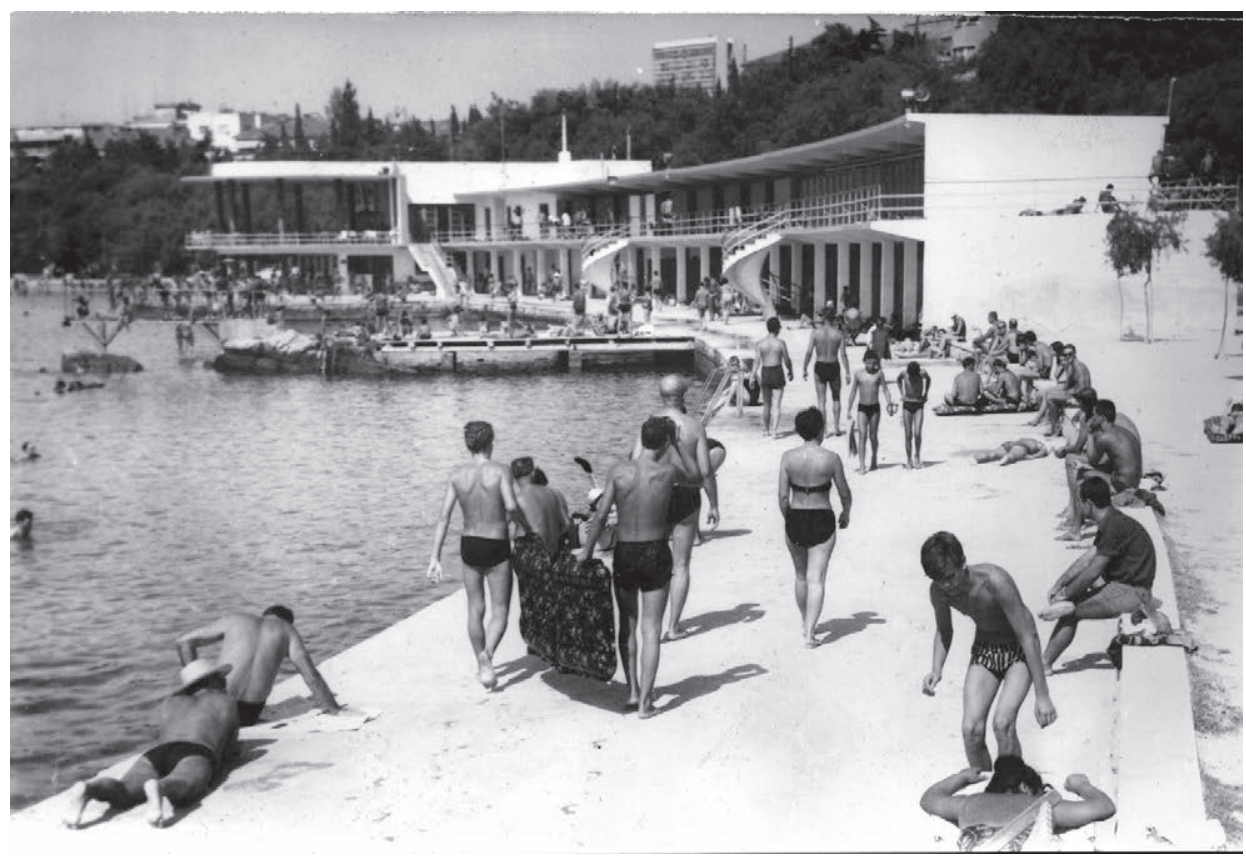

Sl. 9. Kupališna zgrada na Bačvicama. Finalni projekt arhitekata Prospera Čulića i Borisa Katunarića.

konačni nacrt, a prvi radovi su počeli 1938. Koncem godine održana je treća licitacija za izgradnju zgrade kupališta. Nedostajala su sredstva pa su radovi zastali. Na izradi projekta bio je angažiran i arh. Lavoslav Horvat, ali su konačno rješenje napravili Prosper Čulić i Boris Katunarić iz Arhitektonskog odsjeka Općine. Izgradnja je počela 1938. i trajala sve do početka rata. ${ }^{47} \mathrm{U}$ susjednoj je uvali Jugoslavenski pomorski sportski klub Firule sagradio 1923. svoj klub. Drvena zgrada bila je podignuta na stupovima u plićaku. Tako su Bačvice, uz nove hotele, ulice i bogate nasade zelenila, izrasle u visoko kvalitetno stambeno, turističko i rekreacijsko područje.

Sljedeća nešto manja pješčana morska uvala su Firule. Dugo je bila pusta i tiha zbog udaljenosti od grada, ali i zbog tada prisutne odbojnosti prema kupanju. Tek iza Prvoga svjetskog rata tu je počeo zalaziti veliki broj mladića pa je mjesto oživjelo od pjesama i smijeha, cike djece i priča gospođa. Ubrzo su se počela organizirati natjecanja u plivanju. U početku je to bilo neformalno. Zatim je organiziran i pomorski klub. Za njegovo djelovanje trebalo je sagraditi zgradu. U tu svrhu su se prikupljali doprinosi što je išlo dosta teško. Ipak je u plićaku u istočnom dijelu uvale koncem 1923. godine sagrađena baraka na pilonima. U njoj su bile prostorije za članove i upravu, knjižnica, dvorana i spremište za brod. Pred zgradom je bio prostrani plato za sunčanje. Oko kluba se dalje okupljao sve veći broj mladog svijeta, a i kupača koji su uživali u bistrom moru. ${ }^{48}$

Među važnijim radovima na sportskim objektima bilo je i uređenje Hajdukovog igrališta 1923. godine, kada je ono prošireno i izgrađene tribine. Dugo godina se nastojalo podignu-

47 Goran Borčić, 100 godina kupališta na Bačvicama, Split 1992., 1-25; Stanko Piplović, „Uređenje Bačvica između dva svjetska rata“, Bačvice raj na zemlji. Zbornik radova (ur. Zdenko Matošić), Split 2007., 32-49.

48 Ivo Rubić, Firule, Split 1927., 17-24. 
ti klupski dom. Konačno su napori urodili plodom. Nacrt je izradio Boris Katunarić pa je u veljači 1933. počela gradnja. Sport se u Splitu ubrzano razvijao i afirmirao pa se planirala gradnja modernog stadiona, ali to u ovom razdoblju nije ostvareno.

Split ima bogatu sportsku tradiciju, posebno u pomorskim disciplinama. Među prvima je veslačko društvo „Gusar“, osnovano 1913. godine. Oko njega su se okupljali vrsni sportaši, intelektualci pa je to postalo omiljeno mjesto okupljanja i druženja građana. Prve prostorije su mu bile na istočnoj obali luke. Zgrada je najvećim dijelom služila kao spremište čamaca. Imala je i prostorije za upravu, veliku dvoranu i pomoćne sadržaje. S obzirom na pomorske investicije na tom mjestu „Gusar“ se morao iseliti. Odlučeno je podići novu zgradu na malom gatu u lučici. Nacrt je napravio arh. Josip Kodl, i sam veslač. U tu su svrhu prikupljena znatna sredstva donatora, ali se i zadužilo. Radove je izvelo građevinsko poduzeće ing. Ivaniševića. U prizemlju je bilo spremište za čamce, radionica i stan čuvara, a na katu soba uprave, salon i svlačionice. $\mathrm{Na}$ drugom katu nalazila se čitaonica i velika terasa. Zgrada je tlocrtno i visinski bila raščlanjena, a krovovi ravni pa se dobro uklapala u okoliš. Predstavljala je avangardno ostvarenje moderne u našim krajevima. Dom je završen koncem travnja 1927. Svečano je otvoren uz nazočnost velikog broja građana i odličnika. ${ }^{49}$ Ta gradnja predstavljala je početak preobražaja ribarske lučice na razmeđi Rive i Zapadne obale u cjeloviti gradski predjel s poslovnim zgradama, hotelom pa i zračnim pristaništem za hidroavione..$^{50}$

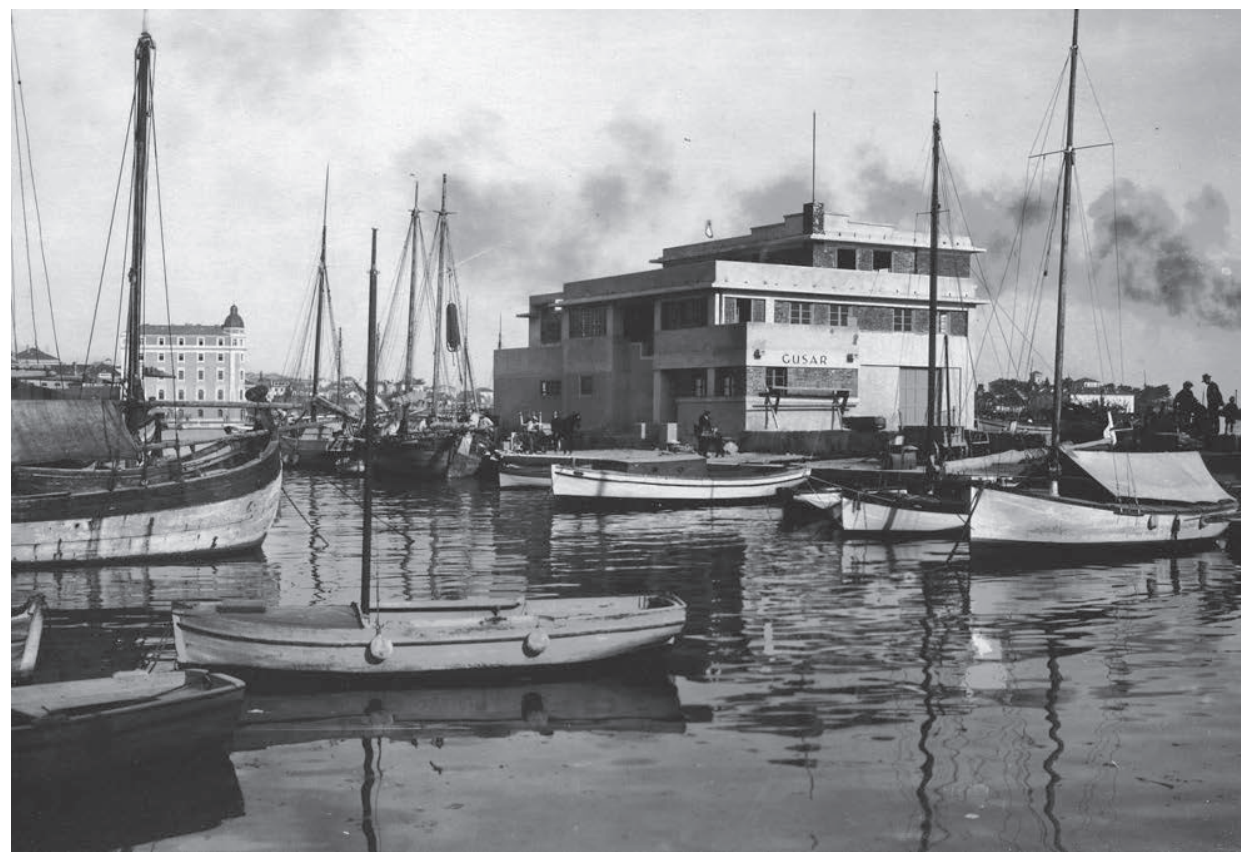

Sl. 10. Dom veslačkog kluba „Gusar“ na Matejuški. Projekt arh. Josipa Kodla.

\footnotetext{
49 Herci Ganza Čaljkušıć, Spomenica HVK Gusar, Split 2014., 16-36.

50 Edo ŠEgvić, Dvi-tri fete Matejuške, Split 2013.
} 
Na zapadnoj strani ulaza u gradsku luku strmo se diže iz mora kameniti poluotok Sustipan. Iza njega su dvije morske uvale - na istoku Baluni, a na zapadu Zvončac - pogodne za smještaj objekata pomorskih sportova. Već 1919. osnovano je pomorsko sportsko društvo „Baluni“. Bio je to prvi plivački klub u Splitu. Godine 1921. sagrađena je velika klupska baraka u uvali Baluni. U istoj uvali se 1924. godine smjestio i sportski klub „Jadran“, koji je također izgradio drvenu baraku i plivalište. Kako je u lučici bilo sve življe, to mjesto više nije bilo pogodno. Stoga se klub preselio u susjednu uvalu Zvončac. Sklop plivališta i kupališta trebalo je urediti pa je u travnju 1936. raspisan natječaj za idejno rješenje bazena i doma. Dostavljeno je osam radova. Prva nagrada nije dodijeljena, već dvije druge i to za zajednički projekt Danku Galetoviću i Slavku Delfinu te Borisu Katunariću. Sudjelovao je i arh. Milorad Družeić, koji je dobio treću nagradu. Izabrano je Delfinovo rješenje pa su radovi počeli u kolovozu. Zatim su 1940. godine sagrađene betonske tribine, za koje je projekt napravio arh. Lovre Perković. ${ }^{51} \mathrm{U}$ uvalu Baluni smjestilo se 1931. i jedriličarsko društvo „Labud“, koje je tu sagradilo dom i uredilo lučicu za brodove. ${ }^{52}$

\section{GRAditeljSKo NASLJEĐE}

Grad je bogat graditeljskim nasljeđem vrlo velike povijesne i umjetničke vrijednosti. To su u prvom redu ostaci Dioklecijanove palače s početka 4. stoljeća, zatim brojne srednjovjekovne kuće i palače te vjerske građevine i sustavi fortifikacija iz vremena renesanse i baroka. Svakodnevni problemi prvih godina nakon rata potisnuli su privremeno probleme uređenja povijesne jezgre Splita. Ipak, Pokrajinski konzervatorski ured za Dalmaciju ulagao je napore da sačuva nadzor nad masovnim pregradnjama unutar nje. Još je neko vrijeme djelovalo i povjerenstvo za Dioklecijanovu palaču, osnovano još za austrijske uprave 1904. godine. Pitanja koja su se u početku rješavala odnosila su se na rušenje Stare biskupije, rješenje graditeljskih spomenika u Regulacionom planu Splita, uređenje kućica prislonjenih uz južni zid Dioklecijanove palače na obali, iskapanje njezinih podzemnih prostorija, popravke i pregradnje privatnih zgrada, regulaciju periptera i okolice carevog mauzoleja te njezinu unutrašnju rasvjetu. ${ }^{53}$

Uvjeti življenja u povijesnoj jezgri bili su veoma loši. Mračni i tijesni prostori u kojima je živjela sirotinja bili su leglo kriminala, prostitucije i bolesti. U dotrajalim zgradama bez komunalnih instalacija često su izbijali požari. Općinska uprava i donekle državna vlast pokušale su popraviti loše stanje rušenjem suvišnih starih kuća, nastojeći otvoriti slobodne prostore i učiniti vidljivijim zaklonjene važnije graditeljske spomenike. I sami vlasnici su nešto poduzimali, naročito preuređivanjem dućana u prizemljima, ali se sve to sporo provodilo. Ispod južnog dijela Dioklecijanove palače nalaze se podrumske prostorije. Služile

51 Goran Borčić, Marjan nekada , Split 2004., 78-80; S. Piplović, „Arhitekt Milorad Družeić“, 263-269.

52 Davor Domančić, „70. obljetnica djelovanja jedriličarskog kluba Labud na Mejama“, Sustipan, 1/1995., br. 1, 19.

53 „Izvješće o djelatnosti Pokrajinskog konservatorskoga ureda za Dalmaciju i Povjerenstva Dioklecijanove palače za 1921. godinu“, Vjesnik za arheologiju i historiju dalmatinsku, 44/1921., Prilog II, 21-36. 
su za izravnanje terena koji je padao prema moru, kako bi se stvorila ravna površina za carev stan iznad njih. $S$ vremenom su zatrpane otpadnim materijalom iz kuća koje su kasnije sagrađene poviše njih. U drugoj polovici 19. stoljeća počelo se $s$ njihovim istraživanjem te čišćenjem iz zdravstvenih razloga i zbog mogućeg korištenja. Za velikih radova u Pučkoj kuhinji na mjestu nekadašnjeg samostana sv. Klare otvoren je pristup odozgo u suteren carske palače. Radilo se o substrakciji zapadne križne dvorane triklinija. Bilo je sporova oko vlasništva pojedinih podzemnih prostora. Konzervator Frane Bulić je zastupao stajalište da je Dioklecijanova palača državno dobro, a kasniji korisnici mogu imati samo pravo služnosti. Dozvoljavao je očistiti prostorije privatnicima.

Prigodom raspisivanja međunarodnog natječaja za Regulacioni plan grada, Bulić je pokrenuo pitanje njihove asanacije. Smatrao je da su podrumi bitno pitanje uređenja starog grada, naročito radi sprečavanja zaraza i neugodnog zadaha. Bio je osnovan i poseban odbor koji je pripremio memorandum o potrebi čišćenja podruma. ${ }^{54}$

Naročito važan dio povijesne sredine bila je katedrala, tj. bivši carev mauzolej i njezin okoliš s Peristilom u samom središtu Dioklecijanove palače. S njezine sjeverne strane nalazila se izdužena zgrada Stare biskupije iz 17. stoljeća. Više nije služila svojoj namjeni. U njoj su bili neki uredi, skladišta i tiskara. Dotrajala, zaklanjala je pogled na mauzolej i ometala pješački promet $\mathrm{u}$ frekventnom dijelu grada pa se raspravljalo se o njezinom rušenju. $\mathrm{O}$ tome su bila različita mišljenja $-s$ jedne strane konzervatora, koji su nastojali očuvati cjelinu ambijenta i s druge arhitekata, koji su se zalagali za rješavanje teških socijalnih, zdravstvenih i prometnih problema u tom dijelu grada. ${ }^{55}$ Duge i oštre rasprave prekinuo je požar u kojemu je 1924. godine izgorjela čitava zgrada pa su njezini ostaci uklonjeni i stvoren široki slobodni prostor na tom mjestu.

Ispred južnog pročelja Dioklecijanove palače podignut je u srednjem vijeku niz kućica prislonjenih na njezin zid. Kako su u novije vrijeme dotrajale, njihovi vlasnici su ih željeli rušiti i na istom mjestu graditi nove. $U$ vezi s tim pojavio se problem: treba li ponovno graditi ili ostaviti slobodan prostor kako bi postao vidljiv donji dio antičkog zida? Odlučeno je ipak da se gradi, ali tako da nove zgrade ne prijeđu visinom donji vijenac kriptoportika južnog pročelja Dioklecijanove palače, kako se ne bi zaklonile arkade. U tu svrhu raspisan je 1922. međunarodni natječaj. Usvojen je prijedlog austrijskog arhitekta Alfreda Kellera po kojemu su kuće postupno izgrađivane. Autor je pokušao oblikovanje prilagoditi tradicionalnom izričaju primorja pa je upotrijebio kose krovove, lučne otvore dućana u prizemlju i razigrane volumene pojedinih dijelova. ${ }^{56}$

U užoj povijesnoj jezgri sačuvano je nekoliko srednjovjekovnih i renesansnih plemićkih palača, koje su u novije vrijeme bile izložene devastacijama zbog promjena njihovih namjena. Dotadašnji vlasnici su ih napuštali pa su se u njih naselili došljaci iz okolice. Novi siromašniji stanovnici prilagođavali su ih svojim svakodnevnim potrebama. U prizemlju

\footnotetext{
54 Stanko Piplović, „Historijat istraživanja podruma Dioklecijanove palače u Splitu“, Kulturna baština, 17/1993., br. 22-23, 72-77.

55 Ljubo Karaman, „Pitanje odstranjenja stare biskupije u Dioklecijanovoj palači u Splitu“, Vjesnik za arheologiju i historiju dalmatinsku, 43/1920., Prilog I, 3-48.

56 Stanko Piplović, „Dalmatinski opus Alfreda Kellera“, Godišnjak Njemačke narodnosne zajednice, 5/1998., 60-61.
} 
sklopa palače D’Augubio otvorena je 1921. gostionica. U Krešimirovoj ulici diže se palača Cindro s baroknim pročeljem. Godine 1920. preuređen je njezin središnji atrij u prizemlju i oko njega otvoreni dućani. Pritom je uništen trijem s renesansnim stupovima, tada jedini u gradu sačuvan još iz tog vremena. Gotička Papalićeva palača u srcu grada, nekadašnje sastajalište humanista, neprimjereno je korištena. Godine 1937. vlasnik joj je prenamijenio prizemlje u gostionicu, a zatim je devastirana i velika dvorana na katu. Iz predvorja palače Milesi na današnjem Trgu braće Radića uklonjena je 1922. godine bogata kruna bunara, a pročelje je narednih godina nagrđeno neukusnim reklamama. Ne samo bogate palače već i obične slikovite kuće bez osjećaja su se prilagođavale novom načinu života.

\section{KOMUNALNI I INFRASTRUKTURNI RADOVI}

Za opskrbu energijom Split je sve do 1919. godine imao samo Gradsku plinaru i to za javnu rasvjetu. Nakon rata postalo je neophodno da se provede elektrifikacija. U početku se donekle pomoglo dobavom iz tvornice cementa u Majdanu iz njezinog postrojenja na rijeci Jadro. Trajno rješenje bio je priključak na tvornicu kalcijeva karbida "Sufid“ u Dugom Ratu kod Omiša jer je ona imala hidrocentralu na rijeci Cetini. Radovi na priključnom dalekovodu bili su gotovi 1927., a do konca iduće godine izvedena je u većem dijelu i gradska mreža. ${ }^{57}$

Tijekom čitavog srednjeg vijeka pa sve do konca 19. stoljeća Split se opskrbljivao vodom iz bunara. $S$ porastom broja stanovnika stvari su se morale promijeniti. Obnovljen je stari Dioklecijanov vodovod pa je grad dobio tekuću vodu. Kako je izvor rijeke Jadro na podnožju brda Mosor bio na dosta maloj visini, voda je gravitacijom dopirala samo do najnižih dijelova grada. Uzdignuti okolni predjeli nisu se mogli priključiti na gradsku mrežu, koja se ipak širila gdje je za to bilo uvjeta. To je bio veliki problem pa su napravljena neka provizorna rješenja. Napokon se 1928. prišlo cjelovitoj rekonstrukciji sustava. Sagrađena su dva spremnika na uzvisinama Marjana i Gripa. U njih se tlačila voda koja se odatle slijevala slobodnim padom u gradsku mrežu. Projekt je napravio ing. Feliks Šperac, a radove je vodio ing. Lovre Manola. Završeni su 1932. godine..$^{58}$

Groblje na poluotoku Sustipanu na zapadnom kraju ulaza u luku uređeno je 1825. godine. $S$ vremenom je popunjeno pa je 1920. prošireno prema istoku i zapadu. Ali ni to nije bilo dovoljno pa se tražila nova lokacija za ukopište. Za to je određen predjel Tršćenica u polju istočno od grada. Općinski arhitekt Josip Kodl napravio je projekt za osnovu po kojoj je izvedena parcelacija te za ulaz, ali on nije izveden. Novo groblje nazvano kasnije Lovrinac otvoreno je 1928. Kako predviđena grobljanska crkva ni kapela nisu sagrađene, za pogrebne obrede služila je obližnja crkvica sv. Lovre od Pazdigrada. Na starom groblju Općina je zabranila daljnje ukopavanje, ali su građani tražili da se ipak odobri koristi grob-

\footnotetext{
57 Branislav Radica, Novi Split, Split 1931., 134-139; Stanko Piplović, „Počeci industrijske izgradnje u Omišu“, Omiški ljetopis, 1/2002., 160-169.

58 Feliks ŠperaC, „Novi vodovod u Splitu“, Tehnički list, 14/1932., br. 8, 97-104.
} 
nice. Banska uprava molbu je odbila. Građani su se i dalje žalili. Konačno je Državni savjet 1932. zabranio svako daljnje ukapanje. ${ }^{59}$

Nakon Prvog svjetskog rata naglo je porastao automobilski promet u gradu i okolici što je uvjetovalo potrebu uređenja ulica i cesta. ${ }^{60}$

\section{ZELENE POVRŠINE}

Grad je oskudijevao u parkovima i nasadima. Na mjestu današnjeg Trga Republike bio je tijekom francuske uprave uređen prvi javni park u gradu. Tijekom Prvoga svjetskog rata je zapušten, ali su početkom 1924. uz bočne rubove zasađeni redovi palma. To drveće je uklonjeno, a površina je 1941. popločana. Na Manušu je general Marmont početkom 19. stoljeća počeo uređivati gradski perivoj. I on je bio zapušten za vrijeme rata. Godine 1919. započela je nova splitska općina njegovo temeljito preuređenje. ${ }^{61}$ Park je s vremenom postao omiljeno šetalište građana. U njemu su se nedjeljom ujutro održavali glazbeni koncerti.

Središnji dio splitske luke ispred grada, popularno nazvan Riva, jedno je od najvažnijih mjesta susreta građana. To je šetnica uz more s dućanima i ugostiteljskim radnjama. Stoga se njezinom uređenju posvetila posebna pozornost. Tlo joj je bilo zemljano, zasađeno stablima murva. Općinsko upraviteljstvo je 1920. odlučilo zamijeniti murve nasadima palma. Tijekom 1921. počelo se $s$ vađenjem postojećeg drveća i sađenjem redova palma kako bi se stvorio mediteranski ugođaj. ${ }^{62}$ To je nastavljeno i idućih godina, a 1926. površina Rive je asfaltirana.

Park-šuma na brdu Marjan počela se uređivati kao rekreacijsko područje još krajem 19. stoljeća. Želja je bila učiniti je pristupačnijom što većem broju ljudi kako bi im se omogućilo uživanje u zelenilu i tišini. ${ }^{63}$ Trebalo je na Marjanu izgraditi putove, a na istaknutim mjestima urediti odmarališta i vidilice odakle se pružao vidik na široku okolicu. Društvo „Marjan“ odlučilo je 1919. godine urediti šumu. Inženjer Petar Senjanović, član njegove uprave, dobio je zadatak predložiti koji su građevinski radovi za to potrebni. On je do 1923. crtao projekte i neposredno upravljao radovima na probijanju putova. Kroz to vrijeme izgrađeno je najprije pristupno stubište koje vodi sa obale gradske luke do Židovskog groblja, gdje je izgrađen prostran plato. Odatle je uz južni zid groblja izgrađen osunčani put do srednjovjekovne crkvice sv. Nikole, zaštićen od vjetra. Nakon toga Senjanović je trasirao put južnim obronkom do Sedla i natrag sjevernom stranom do grada. Na najvišem vrhu je predložio izgradnju platoa s kojeg se pružao vidik na sve strane - prema Kaštelima, moru i otocima. Plato kao i stepenice od prvog vrha do platoa i dalje na zapad prema crkvici sv. Jere izveo je ing. Dane Matošić 1924. godine. Senjanović je zatim 1926. napravio osnovu puta od crkvice prema rtu. ${ }^{64}$

\footnotetext{
9 Duško KečKemet, Splitsko groblje Sustipan, Split 1994., 97-99.

60 Joško BARIĆ, „Početak javnog prijevoza u Splitu“, Kulturna baština, 40/2014., 129.

61 Duško KeČ́nemet, „Javni parkovi u starom Splitu“, Hortikultura, 40/1973., br. 4, 113-114.

62 Goran Borčić, Riva dozvana iz zaborava, Split 2006., 55.

63 Ivo Lozić, „Promet“, Marjane naš Marjane (ur. Ivo Lozić), Split 2001., 121.

64 Petar Senjanović, „Građevinski radovi na Marjanu“, Almanah Jadranska straža za 1926. godinu, Split 1926., 550554; Duško Kečkemet, „Marjan Društvo za zaštitu i unaprjeđenje Marjana“, Marjane naš Marjane. Zbornik radova
} 


\section{ZAKLJUČAK}

Do Prvog svjetskog rata Split se sastojao od jasno razdvojenog povijesnog središta i pučkih predgrađa Velog Varoša, Dobrog, Manuša i Lučca koji su ga okruživali. Neposredno iza njih su bile prigradske vile, a dalje velika polja.

Nakon rata grad je bio zapušten. Ipak, veliki entuzijazam koji je zavladao imao je početne rezultate. Okosnica razvitka bio je Regulacioni plan koji je uz dosta izmjena usmjeravao građenje tijekom dvadesetogodišnjeg razdoblja. Većina natjecatelja koji su sudjelovali u natječaju za njegovu izradu nije poznavala prilike u Splitu, ali je program dobro postavio glavne probleme pa je ipak postignuto kvalitetno rješenje. Pored tog osnovnog dokumenta nešto kasnije su izrađeni i urbanistički planovi predjela koji su se najviše izgrađivali - Bačvica i Meja. Grad se brzo širio u okolna polja koncentrično oko postojećeg grada i njegovih težačkih predgrađa, najviše na istok i zapad uz more te na sjeverozapad u predjel Gripa.

U daljnjem se razvitku sve jasnije izražavalo zoniranje. Uzduž poluotoka na kojemu se grad nalazi postoji vododijelnica. S njezine južne osunčane strane šire se stambeni dijelovi, prostori namijenjeni turizmu i sportu. Sjeverna strana, prema Kaštelanskom zaljevu, dobila je izrazito gospodarska obilježja. Tamo je bilo više prostora za razvitak proizvodnih djelatnosti. Iz užih područja premještena su brodogradilišta i klaonica. Gradila se željeznička ranžirna stanica u Kopilici, velika transformatorska električna postrojenja u Dujmovači i nova teretna luka kod Vranjica. Na istočnu periferiju preseljeni su groblje i bolnica.

Zbog nepovoljnih uvjeta u središtu izmješteni su prema sjeveru neki javni sadržaji. Taj proces je započeo već koncem prethodnog razdoblja. Među njima su Arheološki muzej, Obrtnička škola i Biskupsko sjemenište. Slijedile su izgradnje zgrada općinskih ureda, gimnazije, suda, Vatrogasnog doma, Javne berze rada, Okružnog ureda osiguranja radnika, žandarske vojarne i tako dalje.

U to vrijeme su, iako s dosta financijskih i organizacijskih poteškoća, uglavnom izgrađeni najvažniji javni i infrastrukturni objekti koji su gradu bili potrebni s obzirom na ključnu upravnu i gospodarsku funkciju koju je dobio. Na prvom mjestu to je željeznička veza s unutrašnjošću. Svakako valja imati na umu i izgradnju sjeverne luke, osiguranje električne energije, rekonstrukciju vodovoda i osnivanje novog groblja. Uređene su glavne izlazne ceste prema istoku u pravcu Omiša i sjeveru preko Solina do Trogira. Važna je bila Balkanska cesta, koja je spajala ulazne ceste obilazeći u velikom luku grad.

Tome treba dodati smišljenu stambenu izgradnju, naročito u prvom razdoblju. Sve se ima u velikoj mjeri zahvaliti dobroj politici općinskih uprava kao investitora. Tako je Split u kratko vrijeme postao napredan i moderan grad. Razvijao se smišljeno i skladno. Ipak, gospodarske krize koje su kasnije zahvatile svijet, posebno velika oskudica tridesetih godina, ometale su privatnu stambenu izgradnju. Tome su doprinijele i nerodice. Stanovništvo je prilično osiromašilo, a ni iseljenici nisu više ulagali novac u novogradnje. Građevinska djelatnost gotovo je zamrla. U 1937. privreda je nešto oživjela, ali građevinarstvo nije pokazalo veće rezultate. Slično je stanje bilo i u idućoj godini. ${ }^{65}$

(ur. Ivo Lozić), Split 2001., 33-34; Stanko Piplović, „Uređenje Marjana između dva rata“, Hortikultura, 45/1978., br. 4, 140-142. 
Ubrzo nakon rata izgubili su se elementi neostilske i secesijske arhitekture, značajno prisutni u stvaralaštvu 19. stoljeća. Naredna izgradnja se može podijeliti otprilike u dva desetogodišnja razdoblja. U prvom je još uvijek prisutna tradicionalna podjela pročelja na katove vijencima, prakticiraju se okviri oko otvora i pojednostavljeni ukrasi koji podsjećaju na nedavnu prošlost. Pored toga, arhitektura se vezuje za mediteransku tradiciju pa se koriste razigrani volumeni, elementi lokalne tradicije $s$ kosim krovovima pokrivenim kupom kanalicom, kamen i lučni otvori. U tom smislu karakteristične su kuće Fabjana Kaliterne i Hranka Smodlake. ${ }^{66}$ Nisu zanemarivi ni utjecaji kontinentalnih ostvarenja jer su stariji naraštaji studirali u Beču, Grazu i konačno u Pragu. U početku su još uvijek prisutni arhitekti iz njemačkog govornog područja, posebno Austrijanci, koji su se javljali na natječaje. Među njima su Werner Schürmann i Alfred Keller. U drugome razdoblju zgrade postaju veće, grade se u nizu sa predvrtovima prema ulicama, primjenjuju se vodoravno izduženi prozori i ravni krovovi. Dekoracija se gubi.

U kratkom vremenu od dva desetljeća bilo je dosta intervencija u srednjovjekovnoj jezgri Splita. Osnovni razlozi su bili higijenska sanacija zapuštenog područja i rješavanje prometnih problema. S arheološkog stajališta bilo je važnih rezultata. U pretežno slučajnim nalazima došlo se do bitnih podataka o izvornom rasporedu Dioklecijanove palače. Konzervatorski zahvati na zgradama od povijesnog ambijentalnog i umjetničkog značaja bili su skromni i promjene na njima često su izmicale nadzoru. Nove zgrade nisu se mjerilom uskladile s okolicom. Najviše gradnja je bilo u rubnim zonama, gdje je bilo slobodnog prostora. Ali bilo je i interpolacija u gušćem tkivu. Nakon Drugog svjetskog rata nastavilo se s intenzivnijim istraživanjima i uređivanjem povijesne jezgre Splita, koja je 1979. godine proglašena svjetskom kulturnom baštinom pod zaštitom UNESCO-a.

I pored značajnih rezultata, mnoge zacrtane javne i gospodarske građevine nisu ostvarene. Razlozi su bili u nedostatku novca, a gradnju nekih projekata omeo je Drugi svjetski rat. Tako se osjećala velika potreba za novom zgradom Trgovačke akademije. To pitanje naročito se naglašavalo 1938. godine jer je to bila jedina škola takve vrste u čitavoj Primorskoj banovini, a djelovala je u skučenoj zgradi namijenjenoj stanovanju ${ }^{67}$ Razmatrala se i gradnja silosa za izvoz žitarica na lukobranu, a tvrtka „Export“ iz Splita ponudila je Općini carinskih skladišta za vino. Mnogo se raspravljalo, naročito 1939. godine, o potrebi gradnje nove suvremeno uređene ribarnice. ${ }^{68} \mathrm{U}$ punom jeku razaranja Drugoga svjetskog rata, dok Jugoslavija još nije napadnuta, u Splitu se planirala izgradnja zimskog bazena s grijanom morskom vodom. Za to su bila čak osigurana neka sredstva. ${ }^{69}$

Isto tako su obalni radnici, s obzirom na teške uvjete rada, tražili 1939. da se sagradi njihov dom na lukobranu. U tu svrhu bio je čak izrađen nacrt. Među komunalnim pitanjima koja su se često spominjala, a nisu riješena, bili su i pazar i ribarnica. Njihovi prostori nipošto nisu odgovarali higijenskim uvjetima poslovanja. ${ }^{70}$

\footnotetext{
66 S. Piplović, „Stručno djelovanje Hranka Smodlake“, 153-155.

67 „Gradnju Trg. Akademije“, Novo doba (Split), br. 101, 30. 4. 1938., 5.

68 „Rasprava o izgradnji silosa i skladišta za vino“, Novo doba (Split), br. 227, 28. 9. 1938., 6.

69 „Pitanje zimskog kupališta u Splitu“, „Za izgradnju nove ribarnice“, Novo doba (Split), br. 79, 4. 4. $1940 ., 6$.

70 „Izgradnja moderne ribarnice“, Novo doba (Split), br. 130, 3. 6. 1938., 5.
} 
Splitska sekcija Udruženja jugoslavenskih inženjera i arhitekata (UIJA) bila je dosta aktivna. Održavala je redovno sastanke i skupštine. Najvažniji je događaj bila Glavna skupština UIJA 1923. godine. Na njoj su sudjelovali predstavnici iz cijele države. Priređivali su se stručni izleti za članove, sudjelovalo se u javnim raspravama o važnim pitanjima izgradnje Splita. Tako je koncem svibnja 1938. upriličeno putovanje u Italiju za inženjere hidrotehnike. Potom je u lipnju organiziran posjet kongresu za putove u Haagu. ${ }^{71}$

U kratkom međuratnom razdoblju, pored javnih natječaja za urbanističke planove, organiziran je i veći broj natječaja za javne građevine. Dali su dobre rezultate, iako s dosta manjkavosti u provođenju. Bilo ih je dosta neuspješnih, uglavnom zbog manjkavosti propozicija te nepravilnog rada ocjenjivačkih sudova. Više ih je uzaludno raspisano. Navedimo samo natječaj za kupalište Bačvice, bolnicu i Bansku palaču. Događalo se da su natječaji bili u suprotnostima s Pravilima za raspisivanje natječaja u oblasti arhitekture i inženjerstva iz 1926., a novi Pravilnik o konkursima stupio je na snagu tek 13. listopada 1938. godine. U Splitu je nekoliko godina uoči rata živjelo i radilo oko dvadeset arhitekata, što je za to vrijeme bio priličan broj. Zbog formalnih propusta u natječajima je sudjelovao mali broj natjecatelja, najviše njih dvadesetak. Za razliku od toga, u drugim hrvatskim većim gradovima prijavilo bi ih se gotovo uvijek između šezdeset i osamdeset. ${ }^{72}$

\section{$\cos$}

\section{Urban Development of Split between the World WARS}

Split grew quickly after the First World War. It became an economic, transport and cultural hub of an expansive region. As Zadar, Rijeka and Trieste became parts of Italy, it developed into the main importing and transit harbor in the new state. Its population grew, and housing spread into the surrounding vineyards. From the outset, the city was led by mayor dr. Ivo Tartaglia, who invested much effort into advancing the city. He stayed in power for a full decade, and later served three more years as ban of the Littoral Banovina. He helped build many public buildings for which open competitions were held. Among the most important buildings are those on the seaside in front of the Diocletian Palace's southern wall, the modern bathing area in Bačvica cove, the construction of elementary schools and gymnasiums, the Oceanographic Institute, hospital, Banovina Palace, the Chamber of Trades and Crafts, the Church of Our Lady of Health, hotels, employment office, municipal buildings and others. Their construction was headedd by renowned architects and urbanists from Split, the whole country and also from foreign countries. Completely new areas of the city were built. In order to design a longer term plan for the development of Split, an international competition was held for the Regulatory plan. The first prize was won in 1924 by the German architect W. Schürmann, and his plan was the basis for Split's growth between the wars. It was a time when the historicism and secession styles were being abandoned, and the modern style was

$\overline{71}$ „Iz udruženja jugosl. inženjera“, Novo doba (Split), br. 118, 20. 5. 1938., 6.

72 „O arhitektonskim natječajima u Splitu“, Jadranski dnevnik (Split), br. 277, 26. 11. 1938., 11. 
ushered in, alongside traditional and regional touches. The main representative of pure functionalist architecture was the Czech architect J. Kodl. Apart from notable buildings necessary for the economy, urban management, culture and sports, infrastructure objects were also built. Electric street light was provided, a railroad to the inland was constructed, a northern port was built in the Kaštela Bay, road works to the outskirts of town, the historical center was refurbished. In these twenty dynamic years Split was almost completely transformed in looks and content. The structure of the population changed, and the number increased from around 25.000 to over 50.000. The contacts between people and their mobility expanded, which had an effect on the art of the era.

Keywords: Split, $20^{\text {th }}$ century, urbanism, ambient, construction

\section{$\cos$}

\section{Literatura}

Niko Armada, „Rezultat natječaja i ocjenjivanja juri-a za projekte pučkih škola u Splitu“, Novo doba (Split), br. 227, 13. 9. 1928., 5.

Jasminka BABIĆ, Arhitektonski nacrti galerije Ivana Meštrovića u Splitu, Split 1999.

Joško BARIĆ, „Početak javnog prijevoza u Splitu“, Kulturna baština, 40/2014., 117-135.

Goran Borčić, Marjan nekada, Split 2004.

Goran Borčıć, „O Bačvicama do kraja 19. stoljeća“, Bačvice raj na zemlji. Zbornik radova (ur. Zdenko Matošić), Split 2007., 16-29.

Goran Borčić, Riva dozvana iz zaborava, Split 2006.

Goran Borčić, 100 godina kupališta na Bačvicama, Split 1992.

Sanja Buble, „Hotel Central na splitskoj Pjaci“, Kulturna baština, 40/2014., 225-248.

Ante Crnica, Naša Gospa od zdravlja i njezina slava, Šibenik 1939.

Nikola Dobrović, Urbanizam kroz vekove, sv. 1, Beograd 1950.

Davor Domančıć, „70. obljetnica djelovanja jedriličarskog kluba Labud na Mejama“, Sustipan, 1/1995., br. 1, 18-21.

Arsen Duplančić, „Pitanje izgradnje nove katedrale u Splitu do II. svjetskog rata“, Kulturna baština, 14/1989., br. 19, 108-137.

Herci Ganza Čaljkušić, Spomenica HVK Gusar, Split 2014.

„Izvješće o djelatnosti Pokrajinskog konservatorskoga ureda za Dalmaciju i Povjerenstva Dioklecijanove palače za 1921. godinu“, Vjesnik za arheologiju i historiju dalmatinsku, 44/1921., Prilog II.

Ljubo Karaman, „Pitanje odstranjenja stare biskupije u Dioklecijanovoj palači u Splitu“, Vjesnik za arheologiju i historiju dalmatinsku, 43/1920., Prilog I.

Duško KečKemet, „Arh. Fabijan Kaliterna, Slobodna Dalmacija (Split), br. 9763, 21. 8. 1976., 6.

Duško KečKemet, „Javni parkovi u starom Splitu“, Hortikultura, 40/1973., br. 4, 109-114.

Duško KečKemet, „Marjan Društvo za zaštitu i unaprjeđenje Marjana“, Marjane naš Marjane. Zbornik radova (ur. Ivo Lozić), Split 2001., 30-38.

Duško Kečkemet, Splitsko groblje Sustipan, Split 1994.

Duško Kečkemet, „Stambena arhitektura u Splitu u razdoblju između dva svjetska rata“, Arhitektura, 42-44/1989.-1991., br. 1-3, 25-27.

Duško KečKemet, Stara splitska bolnica, Split 1964. 
Vjekoslav LEvš, „Zgrada glavne bratimske blagajne u Splitu“, Glasnik Primorske banovine, 1/1938., br. 5, 53-54.

Ivo Lozić, „Promet“, Marjane naš Marjane (ur. Ivo Lozić), Split 2001., 118-128.

Norka Machiedo Mladinić, Životni put Ive Tartaglie, Split 2001.

Dragutin Matošıć, „Hranko Smodlaka“, Kulturna baština, 33/2006., 135-149.

Slavko Muljačıć, „Historijat izgradnje priobalnog pojasa u splitskoj luci, od Matejuške do Sustipana (1850-1960)“, Urbs, 3/1959.-1960., 43-66.

Slavko Muljačıć, „Kronološki pregled izgradnje Splita u XIX. i XX. stoljeću“, Zbornik Društva inženjera i tehničara Splita (ur. Slavko Siriščević), Split 1958., 61-96.

Franko Oreb, „Proširenje crkve sv. Dominika u Splitu od 1932-1934.“, Kulturna baština, 8/1982., br. 13, 125-130.

Ivan Ostojıć, Nadbiskupsko sjemenište u Splitu (1700-1790), Split 1971.

Zrinka Paladino, „Djelovanje arhitekta Lavoslava Horvata u Splitu“, Kulturna baština, 37/2011., 191-226.

Zdeslav Perković, „Istraživanje samostana sv. Marije de Taurello“, Kulturna baština, 7/1981., br. $11-12,46-63$.

Stanko Piplović, „Arhitekt Harold Bilinic“, Hrvatska obzorja, 2/1994., br. 4, 847-850.

Stanko Piplović, „Arhitekt Milorad Družeić“, Kulturna baština, 37/2011., 259-316.

Stanko Piplović, „Cementna industrija u Dalmaciji nakon Prvog svjetskog rata“, XVII. savjetovanje o tehničkim dostignućima i proizvodnji cementa (ur. Petar Žižić), sv. 2, Split 1997., H-3-10.

Stanko Piplović, „Dalmatinski opus Alfreda Kellera“, Godišnjak Njemačke narodnosne zajednice, 5/1998., 53-62.

Stanko Piplović, „Graditelji braća Žagar“, Kulturna baština, 32/2005., 325-354.

Stanko Piplović, „Građevine i dobra Splitskog Sjemeništa“, 300. obljetnica splitskoga sjemeništa $i$ klasične gimnazije (1700.-2000.). Zbornik radova (ur. Ivan Banić), Split 2000., 289-340.

Stanko Piplović, „Historijat istraživanja podruma Dioklecijanove palače u Splitu“, Kulturna baština, 17/1993., br. 22-23, 65-82.

Stanko Piplović, „Izgradnja Doma Obrtničke i trgovačke komore u Splitu u kontekstu nastupa moderne“, Kulturna baština, 40/2014., 191-201.

Stanko Piplović, Izgradnja Splita između svjetskih ratova, Split 2008.

Stanko Piplović, „Osnivanje i izgradnja prvih muzeja u Splitu“, Naš museum (ur. Josip Balabanić), Zagreb 1998., 111-126.

Stanko Piplović, „Počeci industrijske izgradnje u Omišu“, Omiški ljetopis, 1/2002., 159-178.

Stanko Piplović, „Radovi na splitskim crkvicama između dvaju svjetskih ratova“, Kulturna baština, 24/2002., br. 31, 311-346.

Stanko Piplović, „Recentne preobrazbe samostanskog kompleksa na Pojišanu“, Kapucinski samostan i svetište gospe od Pojišana u Splitu. Zbornik radova (ur. Arsen Duplančić), Split 2010., 363-393.

Stanko Piplović, „Stručno djelovanje Hranka Smodlake“, Kulturna baština, 33/2006., 153-170.

Stanko Piplović, „Uređenje Bačvica između dva svjetska rata“, Bačvice raj na zemlji. Zbornik radova (ur. Zdenko Matošić), Split 2007., 32-49.

Stanko Piplović, „Uređenje Marjana između dva rata“, Hortikultura, 45/1978., br. 4, 139-142.

Stanko Piplović, „Zgrade sjemeništa i klasične gimnazije u Splitu“, 290 godina klasične gimnazije u Splitu 1700-1990. Zbornik radova (ur. Stanko Piplović), Split 1990., 173-196.

Poziv i pravilnik družtva za gradnju nove stolne crkve u Splitu, Split 1915. 
Robert Plejıć, „Arhitektonski opus Petra Senjanovića“, Petar Senjanović (ur. Robert Plejić), Split 2007., 117-142.

Robert Plejıć, „Splitski arhitekt Niko Armanda, arhitektonski modernizam i povijesni prostor“, Kulturna baština, 37/2011., 227-258.

Branislav Radica, Novi Split, Split 1931.

Lida Roje Depolo - Aleksandar Laslo, Frane Cota, Zagreb 1995.

Ivo Rubić, Firule, Split 1927.

Mirjana Rumboldt, „Uz sedamdesetu obljetnicu Školske poliklinike u Splitu“, 70 godina Školske poliklinike u Splitu, Split 1997., 5.

Petar Senjanović, „Građevinski radovi na Marjanu“, Almanah Jadranska straža za 1926. godinu, Split 1926., 549-557.

Petar Senjanović, „Novi građevinski zakon“, Tehnički list, 13/1931., br. 11, 157-176.

Edo ŠEgvić, Dvi-tri fete Matejuške, Split 2013.

Edo ŠEgvić, „Kuća Arambašin“, Kulturna baština, 39/2013., 235-262.

Maja ŠEParović PAladA, Meštrovićeve Crikvine, Split 2012.

Feliks Šperac, „Novi vodovod u Splitu“, Tehnički list, 14/1932., br. 8, 97-104.

Kamilo TončIć, Dioklecijanova palača i položaj nove katedralke u Splitu, Split 1907.

Ambroz Tudor, „Hotel Ambasador, mjesto i zgrada“, Kulturna baština, 21/1999., br. 30, 289-314.

Darovan Tušek, Arhitektonski natječaji u Splitu 1918-1941, Split 1994.

\section{Periodika}

Jadranski dnevnik (Split), 1938.

Novo doba (Split), 1921. - 1940. 